University of Nebraska - Lincoln

DigitalCommons@University of Nebraska - Lincoln

USGS Staff -- Published Research

US Geological Survey

2015

Interactive Effects of Climate Change with Nutrients, Mercury, and Freshwater Acidification on Key Taxa in the North Atlantic Landscape Conservation Cooperative Region

\author{
Alfred E. Pinkney \\ U.S. Fish and Wildlife Service \\ Charles T. Driscoll \\ Syracuse University \\ David C. Evers \\ Biodiversity Research Institute \\ Michael J. Hooper \\ U.S. Geological Survey \\ Jeffrey Horan \\ U.S. Fish and Wildlife Service
}

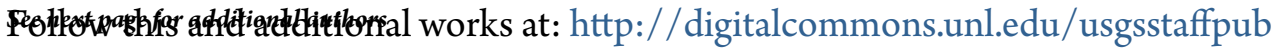

Part of the Geology Commons, Oceanography and Atmospheric Sciences and Meteorology Commons, Other Earth Sciences Commons, and the Other Environmental Sciences Commons

Pinkney, Alfred E.; Driscoll, Charles T.; Evers, David C.; Hooper, Michael J.; Horan, Jeffrey; Jones, Jess W.; Lazarus, Rebecca S.; Marshall, Harold G.; Milliken, Andrew; Rattner, Barnett A.; Schmerfeld, John; and Sparling, Donald W., "Interactive Effects of Climate Change with Nutrients, Mercury, and Freshwater Acidification on Key Taxa in the North Atlantic Landscape Conservation Cooperative Region" (2015). USGS Staff -- Published Research. 962.

http://digitalcommons.unl.edu/usgsstaffpub/962

This Article is brought to you for free and open access by the US Geological Survey at DigitalCommons@University of Nebraska - Lincoln. It has been accepted for inclusion in USGS Staff -- Published Research by an authorized administrator of DigitalCommons@University of Nebraska - Lincoln. 
Authors

Alfred E. Pinkney, Charles T. Driscoll, David C. Evers, Michael J. Hooper, Jeffrey Horan, Jess W. Jones, Rebecca S. Lazarus, Harold G. Marshall, Andrew Milliken, Barnett A. Rattner, John Schmerfeld, and Donald W. Sparling 


\title{
Interactive Effects of Climate Change with Nutrients, Mercury, and Freshwater Acidification on Key Taxa in the North Atlantic Landscape Conservation Cooperative Region
}

\author{
and Donald W Sparling\#\# \\ †US Fish and Wildlife Service, Chesapeake Bay Field Office, Annapolis, Maryland \\ tDepartment of Civil and Environmental Engineering, Syracuse University, Syracuse, New York, USA \\ §Biodiversity Research Institute, Gorham, Maine, USA \\ ||Columbia Environmental Research Center, US Geological Survey, Columbia, Missouri \\ \#US Fish and Wildlife Service, Northeast Regional Office, Hadley, Massachusetts \\ ††US Fish and Wildlife Service, Virginia Tech University, Blacksburg, Virginia \\ $\ddagger \ddagger$ Patuxent Wildlife Research Center, US Geological Survey, Beltsville, Maryland \\ §DDepartment of Biological Sciences, Old Dominion University, Norfolk, Virginia, USA \\ |||US Fish and Wildlife Service, Division of Refuges, Arlington, Virginia \\ \#\#Department of Zoology, Southern Illinois University, Carbondale, Illinois, USA
}

Alfred E Pinkney, ${ }^{*}+$ Charles T Driscoll, $\ddagger$ David C Evers, $\&$ Michael J Hooper, || Jeffrey Horan, \# Jess W Jones, $\dagger \dagger$

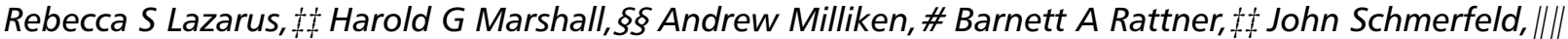

(Submitted 30 April 2014; Returned for Revision 10 June 2014; Accepted 12 December 2014)

\section{ABSTRACT}

The North Atlantic Landscape Conservation Cooperative LCC (NA LCC) is a public-private partnership that provides information to support conservation decisions that may be affected by global climate change (GCC) and other threats. The NA LCC region extends from southeast Virginia to the Canadian Maritime Provinces. Within this region, the US National Climate Assessment documented increases in air temperature, total precipitation, frequency of heavy precipitation events, and rising sea level, and predicted more drastic changes. Here, we synthesize literature on the effects of GCC interacting with selected contaminant, nutrient, and environmental processes to adversely affect natural resources within this region. Using a case study approach, we focused on 3 stressors with sufficient NA LCC regionspecific information for an informed discussion. We describe GCC interactions with a contaminant $(\mathrm{Hg})$ and 2 complex environmental phenomena-freshwater acidification and eutrophication. We also prepared taxa case studies on GCCand GCC-contaminant/nutrient/process effects on amphibians and freshwater mussels. Several avian species of high conservation concern have blood $\mathrm{Hg}$ concentrations that have been associated with reduced nesting success. Freshwater acidification has adversely affected terrestrial and aquatic ecosystems in the Adirondacks and other areas of the region that are slowly recovering due to decreased emissions of $\mathrm{N}$ and sulfur oxides. Eutrophication in many estuaries within the region is projected to increase from greater storm runoff and less denitrification in riparian wetlands. Estuarine hypoxia may be exacerbated by increased stratification. Elevated water temperature favors algal species that produce harmful algal blooms (HABs). In several of the region's estuaries, HABs have been associated with bird die-offs. In the NA LCC region, amphibian populations appear to be declining. Some species may be adversely affected by GCC through higher temperatures and more frequent droughts. GCC may affect freshwater mussel populations via altered stream temperatures and increased sediment loading during heavy storms. Freshwater mussels are sensitive to un-ionized ammonia that more toxic at higher temperatures. We recommend studying the interactive effects of GCC on generation and bioavailability of methylmercury and how GCC-driven shifts in bird species distributions will affect avian exposure to methylmercury. Research is needed on how decreases in acid deposition concurrent with GCC will alter the structure and function of sensitive watersheds and surface waters. Studies are needed to determine how GCC will affect HABs and avian disease, and how more severe and extensive hypoxia will affect fish and shellfish populations. Regarding amphibians, we suggest research on 1) thermal tolerance and moisture requirements of species of concern, 2) effects of multiple stressors (temperature, desiccation, contaminants, nutrients), and 3) approaches to mitigate impacts of increased temperature and seasonal drought. We recommend studies to assess which mussel species and populations are vulnerable and which are resilient to rising stream temperatures, hydrological shifts, and ionic pollutants, all of which are influenced by GCC. Integr Environ Assess Manag 2015;11:355-369. (c) 2014 SETAC

Keywords: Algal blooms Contaminants Global climate change Hypoxia Nutrients

* Address correspondence to: fred_pinkney@fws.gov

Published online 30 December 2014 in Wiley Online Library

(wileyonlinelibrary.com).

DOI: $10.1002 /$ ieam. 1612

\section{INTRODUCTION}

The US National Climate Assessment (Melillo et al. 2014) summarized global climate change (GCC) and its present and potential impacts on the United States. This report and others (IPCC 2007; Lemmen et al. 2008) indicate that the warming of the North American climate is unequivocal and project more 
rapid temperature increases, with changing patterns and intensity of precipitation. In addition to direct effects on plants and animals, GCC causes shifts in the home ranges of species with cascading impacts through ecosystems. For example, the area of the Northeast United States climatically suitable for the Eastern hemlock (Tsuga canadensis) is projected to contract due to warmer winters that favor the spread of a nonnative pest, the hemlock wooly adelgid (Adelges tsugae). Combined effects of climate and pests would not only affect hemlock populations but may result in loss or a geographic shift in associated bird and mammal species. Furthermore, reduced hemlock density may alter soil characteristics enhancing transport of nutrients into streams (Frumhoff et al. 2007).

The release of toxic chemicals and excess nutrients into the environment affects the survival, growth, and reproduction of microorganisms, plants, and animals (Rabelais et al. 2010; Sparling et al. 2010; Coristine and Kerr 2011). The topic of GCC-contaminant interactions was synthesized by Schiedek et al. (2007) and Noyes et al. (2009). A comprehensive investigation of GCC-contaminant interactions was undertaken in 2011 by a Society for Environmental Toxicology and Chemistry (SETAC)-sponsored international workshop (Stahl et al. 2013). A key concept advanced was that GCC, toxicants, and biota interact in 2 primary ways. The first involves changes in chemical distribution and availability to biota that may occur due to GCC. This could result from GCC-induced changes in the physical and/or chemical nature of the contaminant's local environment or from changes in human response to GCC. For example, in response to increased temperature and changes in precipitation, there may be shifts in agriculture and associated pesticide application and changing patterns of power demand and generation (and resulting pollution). The second interaction can occur in biota where toxicity or climate adaptation can be altered. Climate-induced toxicant sensitivities (CITS) are manifested when GCC alters environmental conditions, affecting biochemical and physiological processes and changing responses and sensitivity of organisms to toxicants. Toxicant-induced climate susceptibility (TICS) occurs when a toxicant hinders the ability of an organism to acclimate to environmental conditions altered by GCC (Hooper et al. 2013). Such interactions can potentially affect populations and ecological communities (Moe et al. 2013). Paradigms were suggested for adapting ecological risk assessments (Landis et al. 2013) and natural resource damage assessments (Rohr et al. 2013) to accommodate GCC-contaminant interactions into the environmental regulatory process.

The US Department of the Interior established 22 Landscape Conservation Cooperatives (LCCs) in the United States and adjacent areas of Mexico and Canada as part of a Secretarial Order to address GCC impacts (Salazar 2010). LCCs are geographically based partnerships among federal, regional, and state and/or provincial agencies, Native American tribes, universities, and nongovernmental organizations. LCCs address increasing land use pressures, resource threats, and uncertainties amplified by a rapidly changing climate, enabling the conservation community to enhance and maintain landscapes that sustain natural and cultural resources.

In this article, we discuss GCC interactions with selected contaminants, nutrients, and environmental processes within the North Atlantic LCC (NA LCC) region (Figure 1). This region extends from southeast Virginia north to and including parts of southern Quebec and the Maritime Provinces of
Canada (New Brunswick, Prince Edward Island, and Nova Scotia). Fifty million people live within this 50 million-ha area. Ecoregions and habitat types include freshwater, estuarine, and coastal marine waters; wetlands; agricultural lands; urban and developed lands; and piedmont, coastal plains, and mountains. The primary land cover types are forest (56\%), agriculture (14\%), urban and suburban developed lands (13\%), forested wetlands (9\%), open water (4\%), and emergent marsh (2\%). The NA LCC region includes highly urban and suburban landscapes (e.g., Washington, DC, Baltimore, Philadelphia, New York City, Boston), as well as rural and heavily forested areas.

The region's history of agriculture, forestry, industrialization, resource extraction, and urbanization has placed severe demands on natural resources and the environment. Nevertheless, these ecosystems still support diverse fish and wildlife resources, including threatened and endangered species. The NA LCC (USFWS 2009) list of high priority species for conservation includes threatened and endangered species, as well as those that have experienced population declines and may be subjected to habitat alteration from changes in land use and GCC.

The goal of the current assessment is to provide the NA LCC with a series of demonstrations on how to consider potential threats to natural resources posed by GCC interactions with contaminants, nutrients, and environmental processes. We chose to focus on 5 case studies to illustrate the range of effects, using data from the NA LCC region. We 1) describe how 3 stressors (e.g., eutrophication, $\mathrm{Hg}$, and freshwater acidification) may be affected by GCC, 2) summarize the potential effects of GCC and GCC-stressor interactions on 2 key taxa (amphibians and freshwater mussels), and 3) provide research recommendations for these stressors and taxa.

\section{METHODS}

The NA LCC leadership identified contaminant-climate interactions as a knowledge gap for the partnership and provided funding to address that need. The lead author organized a workshop in June 2012 with a panel of scientists with varied expertise to develop objectives, strategy, and tasks. This process was not, by design, an expert solicitation, but rather an attempt to bring together scientists with a diverse knowledge of regional issues to consider the potential for climate change to exacerbate contaminant impacts. The USFWS Literature Search Service (approximately 30 relevant databases) was used to identify published and unpublished studies that were provided to workshop participants as background information. Searches used terms related to climate change, regions (e.g., Northeast, Adirondacks, Chesapeake Bay), contaminants, and nutrients. More articles were identified through citation searches with Google Scholar (Google, Mountain View, CA) and Web of Science (Thompson Reuters, New York).

We reviewed GCC reports, literature, and models of observed and predicted changes in temperature, precipitation patterns, and sea level rise in the NA LCC region. We discussed the SETAC workshop findings to provide a framework for examining interactions between GCC and toxicants. Just as GCC models have been geographically downscaled for specific regions, we constrained the approach and findings of the SETAC workshop to the NA LCC region.

The authors used their knowledge of ecotoxicology, nutrient cycling, biogeochemical processes, GCC, and experience in 


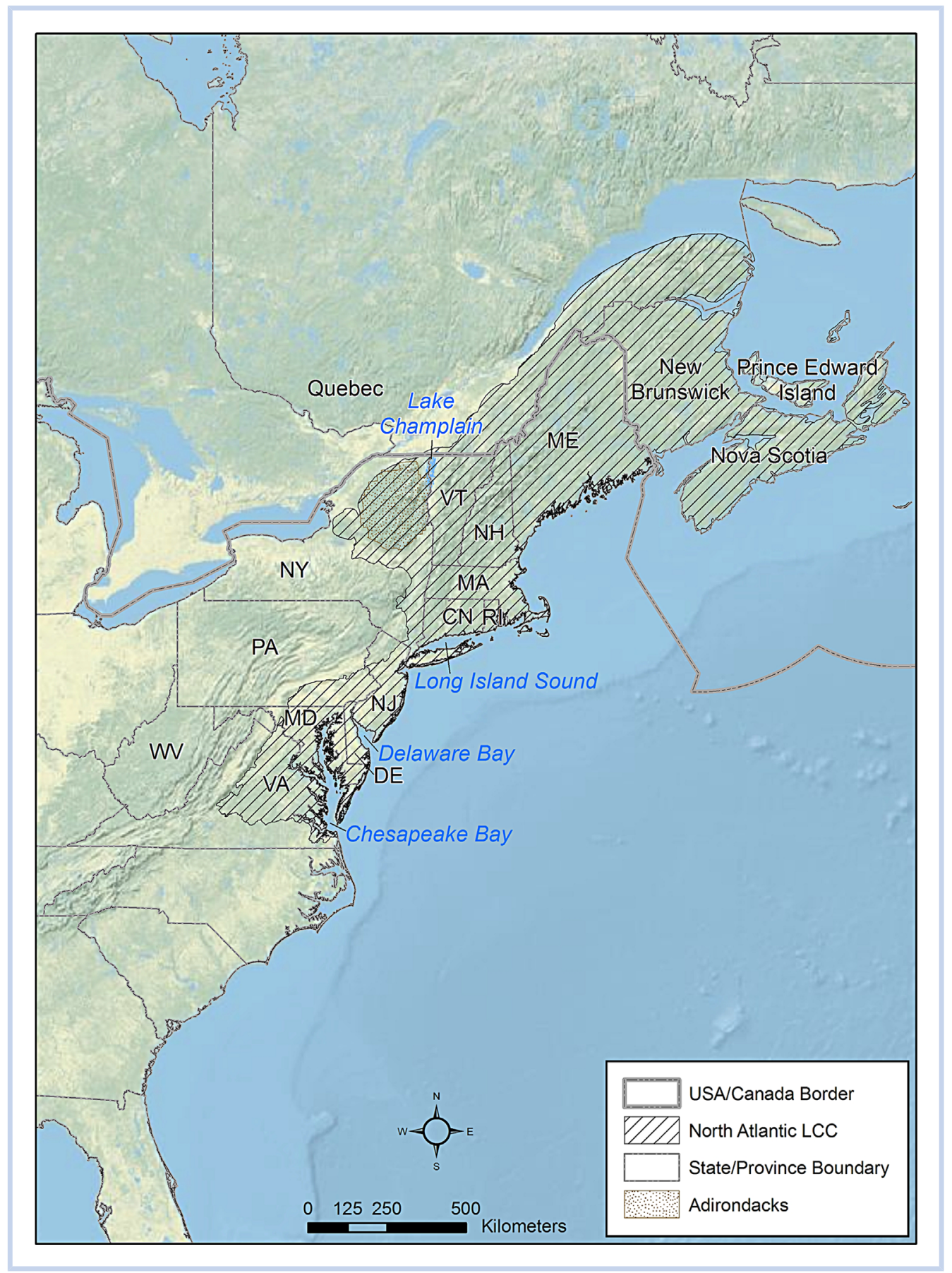

Figure 1. Map of the US Fish and Wildlife Service Northeast Region (Region 5) showing the North Atlantic Landscape Conservation Cooperative.

the NA LCC region to evaluate the available literature. To narrow the universe of chemicals under consideration as case studies, we started with the contaminant groups in the US Environmental Protection Agency (USEPA)/US Geological Survey/USFWS evaluation (2012) of toxic contaminants in the Chesapeake Bay watershed. These were: polychlorinated biphenyls, dioxins and furans, polycyclic aromatic hydrocarbons, petroleum hydrocarbons, pesticides, pharmaceuticals, household and personal care products, polybrominated diphenyl ether flame retardants, biogenic hormones, metals, and metalloids. The list was amended to include road salts because of concerns of the long-term effects of their application on stream ecosystems (Kaushal et al. 2005). Because our scope includes eutrophication and associated effects, nutrients, algal toxins, and hypoxia were included. Finally, the topic of freshwater acidification, a major concern within the NA LCC region, was added.

At present, there are no compounds, chemical groupings, or processes that have an extensive literature base on stressorGCC interactions. For many stressors, the paucity of data would make discussion almost entirely speculative. Thus, we decided to focus on a few stressors for which there was sufficient NA LCC- specific information to prepare examples for an informed discussion. We developed stressor case studies to discuss GCC linkages with: 1) the related and interacting phenomena of eutrophication, hypoxia, and harmful algal blooms (HABs); 2) bioavailability and effects of $\mathrm{Hg}$; and 3) ecosystem responses to freshwater acidification. These issues 
were chosen as examples of the diverse types of contaminant/ nutrient/environmental processes that interact with GCC. In addition to GCC, loadings and effects may be altered by environmental regulations, economic demand, and sensitivity of already impacted landscapes (Staudt et al. 2013).

These 3 stressors were not selected to be prioritized above other contaminants, nutrients, and environmental processes, some of which may be equally important for investigation for GCC interactions but are less well-studied. For example, polychlorinated biphenyls (PCBs), organochlorine pesticides, and polynuclear aromatic hydrocarbons (PAHs) all bind strongly to sediments. Certainly, any GCC processes that facilitate soil and streambank erosion from contaminated areas will increase the release of such compounds from the watershed to water bodies. A variety of taxa may be affected; however, little NA LCC-specific information on GCC linkages with these contaminants was available.

Based on the NA LCC's goal to conserve priority species, we chose to also investigate GCC-contaminant interactions using specific taxa as a focus. Thus, we developed taxa case studies on direct GCC effects and GCC-contaminant/nutrient/process effects on amphibians and freshwater mussels. Conservationists have documented population declines and extinctions of these taxa in many parts of the world, including North America (amphibians: Stuart et al. 2004; Hoffman et al. 2010; Adams et al. 2013; mussels: Williams et al. 1993; Neves et al. 1997). Although in North America, the greatest biodiversity and number of species are found in the US Southern Appalachians (Chaplin et al. 2000), these taxa are key to the functioning of freshwater ecosystems of the NA LCC region. We recognize that many other taxa are affected by GCC, some of which are discussed in the 3 stressor case studies. The holistic focus on these 2 taxa, allowed us to interpret GCC interactive effects of other stressors (e.g., pesticides, ionic pollutants) in addition to the 3 stressor case studies.

\section{CLIMATE CHANGE IN THE NA LCC REGION}

The consequences of GCC in the United States were recently summarized in the National Climate Assessment (Melillo et al. 2014). This report features regional analyses including the Northeast states (WV through ME) (Horton et al. 2014), which overlap the NA LCC region. Other reports have focused on geographic areas relevant to the NA LCC such as Canada (Lemmen et al. 2008; Coristine and Kerr 2011), Chesapeake Bay watershed (Najjar et al. 2010), and Lake Champlain basin (Stager and Thill 2010). Although climate within the Northeast region is diverse and variable, the overall documented changes described by Horton et al. (2014) were

1. Between 1895 and 2011, average annual temperatures increased by almost $1.1^{\circ} \mathrm{C}$;

2. Between 1895 and 2011, average annual precipitation increased by approximately $12.7 \mathrm{~cm}$;

3. Sea level increased by approximately 0.3 meters since 1900 , exceeding the global average by $50 \%$, which has increased susceptibility to storm surges and resulted in more coastal flooding.

4. Between 1958 and 2010, the amount of precipitation falling in very heavy events increased by $74 \%$. This change was greater than that in any other US region.

Horton et al. (2014) summarized the following projected changes that would occur in the region under International
Panel on Climate Change (IPCC 2007) scenarios (A2 and B1) with varying emission rates of heat-trapping gases as follows: 1) increases in the frequency, intensity, and duration of heat waves; in the southern part of the region there may be a doubling of days per year with maximum temperatures greater than $35^{\circ} \mathrm{C}$ by the 2050s; 2) changes in precipitation are less certain but include projections for increasing winter precipitation, frequency of heavy downpours (with river flooding), and seasonal drought; and 3) global sea levels are projected to rise between $0.3 \mathrm{~m}$ and $1.2 \mathrm{~m}$ by 2100 , with the rise in the Northeast exceeding the global average by up to $10 \mathrm{~cm}$; occurrence of coastal flood events could triple by 2100 .

We analyze the interactive effects of these documented and projected climatic changes within the NA LCC region with the following stressor and taxa case studies.

\section{STRESSOR CASE STUDIES}

\section{Mercury}

Mercury $(\mathrm{Hg})$, a contaminant of concern, is distributed worldwide largely as a result of atmospheric emissions and long range transport. Approximately one-third of atmospheric $\mathrm{Hg}$ emissions are from direct anthropogenic sources, the largest of which are coal-fired power plants, cement production, and artisanal gold mining. The remaining two-thirds of emissions are from natural sources, such as volcanoes, burning biomass, and remobilization of previously deposited $\mathrm{Hg}$ (Driscoll et al. 2013). In the NA LCC region, most $\mathrm{Hg}$ is derived from regional (eastern North American) and global sources (Driscoll, Han et al. 2007), but there are local effects from industrial waste site and urban releases (Nobis Engineering 2008). After deposition, Hg may be sequestered in soil, reemitted to the atmosphere or transported from the watershed to surface waters. Bacterial transformation of inorganic $\mathrm{Hg}$ into methylmercury $(\mathrm{MeHg})$, which strongly biomagnifies in aquatic and terrestrial food webs, is most active under reducing conditions in sediments of wetlands, riparian zones, intertidal areas, and coastal waters. Human exposure to $\mathrm{MeHg}$ occurs largely through fish consumption.

$\mathrm{MeHg}$ can threaten the integrity of terrestrial and aquatic ecosystems by adversely affecting the physiology, behavior, and reproductive success of high trophic level species. Residueeffect thresholds (i.e., concentrations associated with adverse effects) have been proposed for fish (Sandheinrich and Wiener 2011; Shore et al. 2011), avian piscivores (Evers et al. 2008; Depew et al. 2012), and avian invertivores (Jackson et al. 2011). The Canada Council of Ministers of the Environment (CCME 2000) issued national water quality criteria for the protection of wildlife from food-chain derived $\mathrm{MeHg}$. As of 2011, all 50 US states had fish consumption advisories due to $\mathrm{Hg}$ contamination. There are statewide or lake-specific $\mathrm{Hg}$ advisories for freshwater habitats in all NA LCC states, the 4 Canadian provinces, and in coastal waters of Connecticut, Rhode Island, Massachusetts, New Hampshire, and Maine (USEPA 2013a; Schmeltz et al. 2011). Many advisories are restricted to top predator species and limits are often more stringent for children and women of childbearing age.

The NA LCC region includes ecosystems that are particularly sensitive to $\mathrm{Hg}$ inputs. Forested areas are effective in scavenging $\mathrm{Hg}$ from the atmosphere and exhibit limited losses from evasion (land-atmosphere exchange). The production of $\mathrm{MeHg}$ in sediments is mediated by sulfate and Fe-reducing bacteria; factors that affect methylation include temperature, 
hydrology, hydrological regime (drawdowns of reservoirs), and the concentration of dissolved organic matter (Driscoll et al. 2013). Abundant wetlands within the NA LCC region promote the formation of $\mathrm{MeHg}$ and supply dissolved organic carbon (DOC) that facilitates the transport of $\mathrm{Hg}$ to downstream surface waters. Low productivity surface waters in the Adirondacks and other northeastern states impacted by acidic deposition exhibit elevated concentrations of $\mathrm{Hg}$ in fish and aquatic wildlife (Driscoll, Han et al. 2007; Yu et al. 2011). In addition, production of $\mathrm{MeHg}$ in sediments of estuarine and coastal wetlands and intertidal and shelf zones contributes to contamination of coastal fisheries (Chen et al. 2009, 2012).

Evers et al. (2007) defined biological $\mathrm{Hg}$ hotspots as locations that, when compared to surrounding landscapes, are characterized by concentrations of $\mathrm{Hg}$ in biota (e.g., fish, birds, mammals) that exceed human or wildlife health criteria. The NA LCC region contains many such hotspots, as evidenced by elevated $\mathrm{Hg}$ in fish tissue and common loon (Gavia immer) blood. Examples include parts of the Adirondacks and Nova Scotia; several reservoirs subject to drawdown and flooding cycles in New Hampshire and Maine; and areas with high local $\mathrm{Hg}$ inputs from hazardous waste sites (e.g., Sudbury River, Massachusetts) (Nobis Engineering 2008).

Within the NA LCC region, elevated MeHg concentrations have been reported in fish (Kamman et al. 2005), amphibians (Bergeron et al. 2011), reptiles (Bergeron et al. 2007), birds (Evers et al. 2005, 2008; Jackson et al. 2011), and mammals (Yates et al. 2005, 2014). Elevated Hg concentration was associated with impaired reproduction in common loons (Gavia immer) collected from lakes in New Hampshire and Maine (Evers et al. 2008). In loons from New Brunswick and Nova Scotia lakes, decreased productivity was associated with elevated $\mathrm{Hg}$ in loon blood or prey fish (Burgess and Meyer 2008). Bird species of high conservation concern, such as the saltmarsh sparrow, Ammodramus caudacutus (Lane et al. 2011), and the rusty blackbird, Euphagus carolinus (Edmonds et al. 2010), also have $\mathrm{Hg}$ body burdens at concentrations associated with reduced nesting success in the Carolina wren (Evers et al. 2011; Jackson et al. 2011). In a study on 21 salt marshes including 5 National Wildlife Refuges (NWRs) from New York through Maine, Lane et al. (2011) found the highest blood $\mathrm{Hg}$ concentrations in saltmarsh sparrows on Parker River NWR (Massachusetts), which receives flow from Hg-contaminated interior watersheds. The authors suggested that GCC-related stressors, including higher temperature, rising water levels, and/or changes in wetting-drying regimes, could increase $\mathrm{Hg}$ bioavailability in coastal wetlands.

We anticipate that aspects of GCC such as higher temperatures and changes in precipitation will alter the transport, net methylation, and trophic transfer of $\mathrm{Hg}$ (Chen et al. 2012). For example, Selvendiran et al. (2008) observed marked increases in net $\mathrm{MeHg}$ production associated with seasonal elevation in temperature in an Adirondack forest watershed wetland. Whether GCC will increase or decrease soil moisture in forests is uncertain (Groffman et al. 2012), and therefore, until projections in soil moisture and its seasonal change can be improved effects on $\mathrm{Hg}$ methylation will not be predicted effectively.

A meta-analysis demonstrated a positive relation between $\mathrm{MeHg}$ bioaccumulation in aquatic food webs and latitude such that trophic magnification was greater in polar and temperate zones versus tropical zones (Lavoie et al. 2013). The mechanism underlying this pattern is not clear, but implies an inverse relationship between trophic transfer of $\mathrm{MeHg}$ and the higher temperatures anticipated under GCC. In field and laboratory studies with the mummichog, Fundulus heteroclitus, however, Djikstra et al. (2013) reported greater whole body $\mathrm{MeHg}$ concentrations at higher temperatures. The field studies used mesh enclosures to restrict the fish from moving between salt marsh pools located along the Gulf of Maine coastline. Fish were exposed to sediments containing $\mathrm{Hg}$, and there was a natural temperature gradient in the pools similar to GCCprojected increases of $1.5^{\circ} \mathrm{C}$ to $4.5^{\circ} \mathrm{C}$ for temperate waters. In the laboratory, fish were exposed to dietary $\mathrm{Hg}$ for 30 days at temperatures of $15^{\circ} \mathrm{C}, 21^{\circ} \mathrm{C}$, or $27^{\circ} \mathrm{C}$. In both laboratory and field studies, there was a significant positive relationship between whole body $\mathrm{Hg}$ accumulation and temperature.

A temperature-Hg interaction was reported by Hallinger and Cristol (2011) in a field study in Virginia in free-ranging tree swallows (Tachycineta bicolor). Breeding success was evaluated from nest boxes at $19 \mathrm{Hg}$-contaminated sites (mean blood $\mathrm{Hg}: 3.03 \mu \mathrm{g} / \mathrm{g}$ ) and 17 reference sites (mean blood $\mathrm{Hg}$ : $0.16 \mu \mathrm{g} / \mathrm{g}$ ). Birds were also exposed to varied ambient temperature and precipitation throughout the breeding cycle. High $\mathrm{Hg}$ concentrations were associated with reduced hatching and fledging success, and highly exposed birds produced approximately one less fledgling per nest than their reference counterparts. Unusually high ambient temperatures early in the nestling period were associated with reduced reproductive output in polluted sites but not in reference birds. In contrast, little effect of $\mathrm{Hg}$ on success of nestlings was observed when temperatures were cooler, and precipitation had no detectable interaction with Hg. Importantly, this study represents the first documentation of negative effects associated with the interaction of GCC metrics and $\mathrm{Hg}$ exposure in a bird population. Potential mechanisms of GCC induction of increased $\mathrm{Hg}$ toxicity (TICS) as well as Hg impacts on climate adaptation (CITS) were proposed and demonstrated using an adverse outcome pathway (AOP) approach incorporating toxicity and climate adaptation pathways (as described in Hooper et al. [2013] and shown in Figure 2).

Adult common loons in the Rangeley Lakes Region of Maine and New Hampshire with low $\mathrm{Hg}$ concentrations exhibited little change in chick production regardless of rainfall (D. Evers, Biodiversity Research Institute, personal communication). Adults with elevated $\mathrm{Hg}$ concentrations, however, produced significantly fewer fledged young during the wettest summers. It was thought that adults with lower $\mathrm{Hg}$ concentrations exhibited adaptively plastic behaviors that allow adequate fledging success rates across a range of climatic conditions. Adults with elevated $\mathrm{Hg}$ concentrations appeared to have less adaptive plasticity, resulting in lowered fitness in wet conditions (an example of TICS, Figure 2) (Hooper et al. 2013)

\section{Freshwater acidification}

Acidic deposition is largely comprised of sulfuric and nitric acid derived from sulfur dioxide $\left(\mathrm{SO}_{2}\right)$ and mono-nitrogen oxides $\left(\mathrm{NO}_{\mathrm{x}}\right)$, respectively. These compounds are emitted to the atmosphere primarily by the burning of fossil fuels. Reduced N, largely in the form of ammonia from agricultural emission sources also contributes to acidification (Driscoll et al. 2003). Acidic deposition continues to alter soils in sensitive areas of the NA LCC region, including the Central Appalachians, the Catskills, and Adirondack regions of New York 


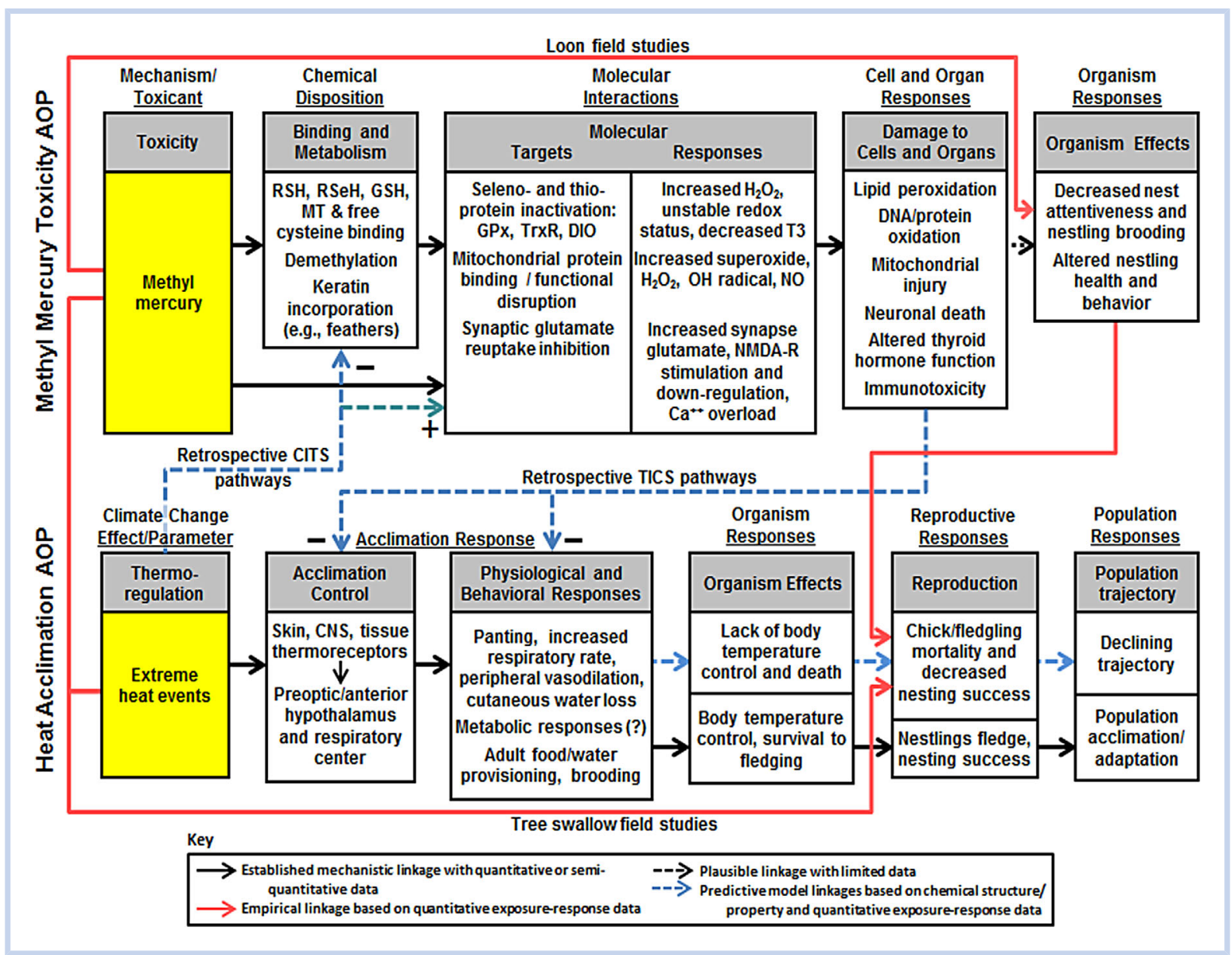

Figure 2. Adverse outcome pathways (AOPs) for investigating direct effects of $\mathrm{Hg}$ on adult brood care (Evers et al. 2008) and combined effects of extreme heat events and $\mathrm{Hg}$ toxicity in tree swallow nestlings (Hallinger and Cristol 2011). Retrospective pathways for potential climate-induced toxicant sensitivity (CITS) and toxicant-induced climate sensitivity (TICS) mechanisms are indicated. DIO = iodothyronine deiodinase; $\mathrm{GPx}=$ glutathione peroxidase; $\mathrm{GSH}=$ reduced glutathione; $\mathrm{H}_{2} \mathrm{O}_{2}$ = hydrogen peroxide; $\mathrm{MT}=$ metallothionein; NMDA-R = N-methyl-D-aspartic acid receptor; $\mathrm{NO}=$ nitric $\mathrm{oxide} ; \mathrm{OH}=\mathrm{hydroxyl} ; \mathrm{RSH}=$ protein thiol; $\mathrm{RSeH}=$ protein selenol; $\mathrm{T} 3=$ triiodothyronine; TrxR =thioredoxine reductase. Modified from Hooper et al. (2013).

and forest upland portions of New England and the Maritimes. Effects in soil include depletion of available calcium $\left(\mathrm{Ca}^{2+}\right)$, magnesium $\left(\mathrm{Mg}^{2+}\right)$ and other nutrient cations from exchangeable sites, and greater accumulation of $\mathrm{S}$ and $\mathrm{N}$. Acidic deposition contributed to declines of red spruce (Picea rubens) and sugar maple (Acer saccharum) through leaching and depletion of $\mathrm{Ca}^{2+}$ and mobilization of $\mathrm{Al}$ (Driscoll et al. 2001). Surface water quality is degraded through lowered $\mathrm{pH}$, diminished acid-neutralizing capacity (ANC), and increased dissolved inorganic $\mathrm{Al}$ concentrations. Although emissions of $\mathrm{SO}_{2}$ have decreased over the past 20 years (see below), concentrations of $\mathrm{SO}_{4}{ }^{2-}$ in streams in acid-impacted regions, such as the forested uplands of the NA LCC region, generally remain high compared to background (Fakhraei et al. 2014).

The Adirondacks (Figure 1) is the region in North America most affected by acidic deposition (Driscoll et al. 1991). In a 1991-1994 study of 1812 Adirondack Lakes $>1$ ha in area, $41 \%$ were chronically acidic or sensitive to episodic acidification (Driscoll et al. 2001). Seasonal acidification occurs from the winter and spring pulse of acidity and the corresponding decrease in $\mathrm{pH}$ and $\mathrm{ANC}$ in streams (Wigington et al. 1996). Episodic acidification occurs in spring snowmelt and large rain events, resulting in sudden pulses of acids and increases in concentrations of dissolved inorganic Al (Baker et al. 1996). In many streams and lakes, decreased $\mathrm{pH}$ and increased dissolved inorganic $\mathrm{Al}$ have resulted in physiological changes, greater mortality of sensitive life history stages, and reduced diversity and abundance of aquatic life including zooplankton, macroinvertebrates, and fish (Driscoll et al. 2001).

GCC may adversely affect sensitive tree species in the NA LCC region. This would occur through drought stress and increases in soil freezing anticipated with rising temperature and shifting runoff patterns from early loss of snowpack (Tierney et al. 2001; Smithwick et al. 2013). Snowpack insulates the soil during winter. Under low snowpack conditions, soil freezing events result in the mortality of fine roots, which limits $\mathrm{N}$ uptake by trees during the following growing season and contributes to elevated $\mathrm{NO}_{3}{ }^{-}$loss and associated acidification.

As a result of the Clean Air Act Amendments of 1990 (CAAA) and the $\mathrm{NO}_{\mathrm{x}}$ Budget Trading Program (NBP, initiated in 2003), there have been marked declines in emissions of $\mathrm{SO}_{2}$ and $\mathrm{NO}_{\mathrm{x}}$ and acidic deposition. From 1990 through 2009, there was a $64 \%$ decrease in $\mathrm{SO}_{2}$ and a $70 \%$ decrease in $\mathrm{NO}_{\mathrm{x}}$ emissions from CAAA and NBP sources nationally (USEPA 2009). Continuous and significant decreasing trends in wet $\mathrm{SO}_{4}{ }^{2-}$ deposition have been observed in Adirondack NY lake watersheds (Waller et al. 2012), declining $33 \%$ over the study period (1991-2007). Annual wet $\mathrm{NO}_{3}{ }^{-}$ 
deposition decreased by $32 \%$ during the same period. Regional trends in surface water chemistry indicate that acid-sensitive lakes and streams throughout the NA LCC region are recovering slowly in response to decreased acid deposition (Driscoll, Driscoll et al. 2007; Stoddard et al. 1999 2003). For example, the percentage of acidic Adirondack lakes (ANC $<0 \mu \mathrm{eq} / \mathrm{L}$ ) decreased from $15.5 \%$ (284 lakes) to $8.3 \%$ (152 lakes) since implementation of the regulations (Waller et al. 2012). Coincident with decreases in acidic deposition and recovery of the acid-base status of soils and surface waters, there has been a compensatory increase in concentrations of dissolved organic carbon (DOC) (Driscoll, Driscoll et al. 2007). These increases in DOC can affect chemical and biological endpoints of recovery from acidification, including the toxicity of $\mathrm{Al}$ and the extent of thermal stratification in Adirondack Lakes.

It is difficult to assess the extent to which changing climate in the NA LCC region will alter recovery from acidic deposition. Greater overall precipitation and heavier storms would result in greater runoff along the top layers of soil (Chen et al. 1984) that could delay acidification recovery. In contrast, diminished peak discharge during snowmelt associated with loss of snowpack due to higher temperatures would decrease the severity of episodic acidification and associated effects. Pourmoktarian et al. (2012) conducted long-term simulations of hydrochemical responses to future changing climate at Hubbard Brook Experimental Forest in New Hampshire. Their models predicted that increases in temperature projected for the region in future decades will increase net mineralization and leaching of soil nitrogen that accumulated from decades of atmospheric nitrogen deposition. This condition resulted in marked acidification of soil and surface waters due to elevated $\mathrm{NO}_{3}{ }^{-}$leaching, causing more severe conditions than had occurred during historical and current acidification from acidic deposition. These simulations also indicated that, in the future, peak conditions of acidification in streams will shift from the spring to the fall. This shift would result in a reduced pulse of toxic monomeric $\mathrm{Al}$, which is released largely by snowmelt (Murdoch and Stoddard 1992).

\section{Eutrophication, harmful algal blooms, and hypoxia}

Anthropogenic eutrophication (enrichment of waters by N, $\mathrm{P}$, and the resulting plant growth) is a major concern in coastal, estuarine, and fresh waters of the NA LCC region. Factors responsible include runoff of nutrients from agricultural fertilizers and animal wastes, loadings from wastewater treatment, volatilization and subsequent deposition of ammonium from fertilizers and animal wastes, and atmospheric deposition of nitrogen oxides from fossil fuel combustion (Rabalais et al. 2009 2010). Two eutrophication-associated phenomena are hypoxia (waters with $<2 \mathrm{mg} / \mathrm{L}$ dissolved oxygen [DO] concentrations) and algal blooms, including HABs that are toxic to fish, wildlife, and humans.

Projected GCC-related increases in surface water temperature and the altered patterns of precipitation are predicted to exacerbate eutrophication due to greater release and runoff of nutrients to water bodies as diverse as Chesapeake Bay (Najjar et al. 2010) and Lake Champlain (Lake Champlain Basin Program 2012). Howarth et al. (2006) projected that riverine loadings of $\mathrm{N}$ to northeastern US estuaries will increase in response to GCC-driven higher precipitation and discharge, primarily due to decreases in denitrification in riparian wetlands and low-order streams. They projected that $\mathrm{N}$ fluxes from the Susquehanna River to Chesapeake Bay by 2095 may be $16 \%$ to $65 \%$ greater than in the 1988 to 1993 base period. Using the Howarth et al. (2006) forecasts and the IPCC (2007)-based predictions of increased water temperature, Prasad et al. (2011) calculated that the volume of anoxic $(<0.2 \mathrm{mg} / \mathrm{L}$ DO) water in the Chesapeake Bay could grow by $3 \%$ to $17 \%$ by 2030 and $16 \%$ to $65 \%$ by 2095 .

The multiple and interacting stressors leading to eutrophication, HABs, and hypoxia in coastal waters are illustrated in Figure 3 (Rabelais et al. 2014). Here, "anthropogenic activities" include nutrients released from agriculture, wastewater treatment plants, and nonpoint source runoff; and changes in hydrology due to agriculture and urbanization. Positive $(+)$ interactions designate worsening conditions related to algal blooms and hypoxia, and negative $(-)$ interactions designate fewer algal blooms and lessening of hypoxia symptoms. Thus, both GCC and non-GCC related stressors can change the extent and severity of hypoxia and HABs.

A major GCC-related concern is the predicted change in composition and distribution of phytoplankton populations, including the greater presence of toxin producing species. These toxins, if ingested, can poison shellfish, fish, wildlife, domestic animals, and humans (Carmichael 1994; Codd 1995). The algal species in estuaries and oceans releasing these toxins include dinoflagellates, diatoms, cyanobacteria, and raphidophytes. Among these, the cyanobacteria are considered to have a competitive edge over many other algae under projected future climate conditions (e.g., warmer temperatures, increased stratification) and thus are predicted to become more dominant (Carey et al. 2012; O'Neil et al. 2012). Anticipated changes in algal composition and productivity resulting from changing anthropogenic stressors, greater eutrophication, and GCC would also influence existing algal predator-prey relationships (Balayla et al. 2010; Winder and Schindler 2004). Changing environmental and biotic relationships associated with greater eutrophication are also projected to favor development of sporadic or frequent blooms by indigenous or invasive species in estuarine and freshwater habitats (Paerl and Huisman 2009; Lürling et al. 2013).

There is evidence that HABs appear to be an expanding problem within several northeast estuaries that may be exacerbated by GCC. For the Chesapeake Bay, there is a long-term trend of increased phytoplankton biomass and abundance, including the presence of $37 \mathrm{HAB}$ taxa from the Bay and tidal tributaries (Marshall et al. 2009). Although many bloom producing algae do not produce toxins, the aftermath of any large algal bloom may include cell decomposition that is often accompanied by hypoxia and major fish kills. Among potentially harmful bloom producers in the Bay are the dinoflagellates, Cochlodinium polykrikoides and Alexandrium monilatum. The former has expanded its range and bloom development in lower Chesapeake Bay over the past several decades, and the latter is an invasive species that produced modest reoccurring blooms in the Bay, and the James and York Rivers in Virginia since 2007 (Marshall and Egerton 2009a 2009b). Another dinoflagellate associated with frequent bloom development in Maryland and Virginia estuaries in the past decade is Karlodinium veneficum, a known fish-killing species (Goshorn et al. 2004; Marshall and Egerton 2009a). In New England waters, blooms of C. polykrikoides (Gobler et al. 2008) and the pelagophyte Aureococcus amophagefferens 


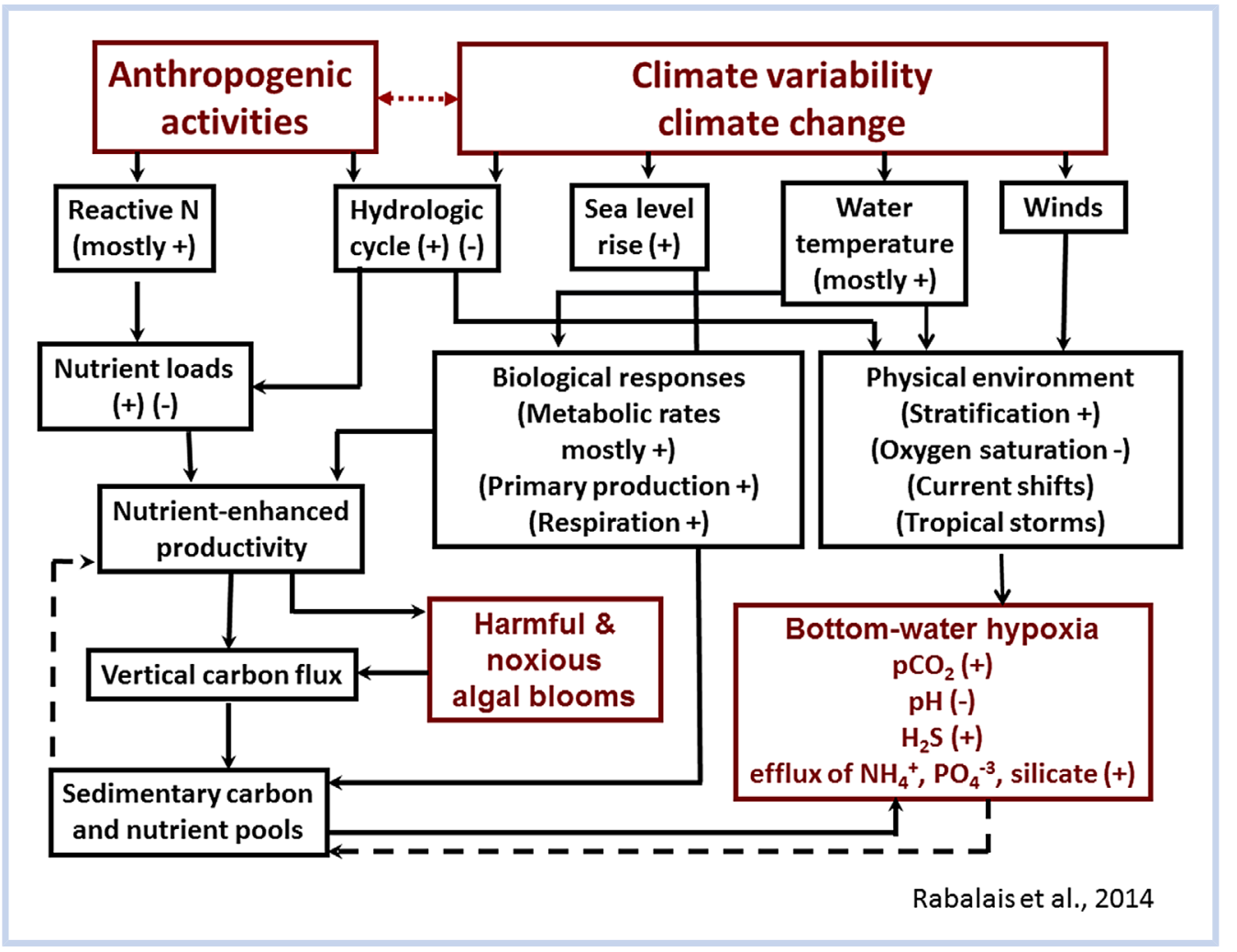

Figure 3. Potential physical and hydrological changes resulting from climate change and their interaction with current and future human activities. The dashed lines represent negative feedback to the system. (Reprinted from Rabalais et al. (2014), with permission).

(Gobler and Sunda 2012) have been documented in relation to nutrient loading.

Lakes within the NA LCC region will also be affected by climate-related factors (e.g., increasing water temperatures, nutrient enrichment, lengthened growing season, and stratification) that affect algal populations (Carey et al. 2012). More frequent outbreaks of HABs were identified as a threat to Lake Champlain (Stager and Thill 2010). Because many reservoirs in the NA LCC region were built decades ago, they are passing into advanced trophic stages that favor $\mathrm{HAB}$ development. In a recent survey of 46 Virginia lakes and reservoirs, HAB cyanobacteria, represented by Microcystis aeruginosa, Aphanizomenon flos-aquae, Anabaena spiroides, Anabaena circinalis, Limnothrix redekei, and Cylindrospermopsis raciborskii were present (Marshall 2013). At least one of these HAB species was observed in 27 of the lakes surveyed. Human health effects associated with ingestion of Microcystis aeruginosa cyanotoxins include hepatic and gastro-intestinal illness, and death (Kuiper-Goodman et al. 1999).

Recent autumnal die-offs of hundreds of migratory birds in Chesapeake Bay $(2001,2004$, and 2005) appear to be linked to HABs. The most prominent events were at the Paul S. Sarbanes Ecosystem Restoration Project at Poplar Island (PSSERPPI) near brackish impoundments. Dead and dying great blue herons (Ardea herodias) were observed and 9 of 22 specimens sent for analysis had detectable quantities of microcystins in the liver (B. Rattner, USGS, personal communication). Necropsies revealed steatitis (excessive abdominal deposits of waxy yellow fat); one of several hypotheses suggests that this condition results from exposure to microcystins in water or prey (Falconer 2005; Armado and Monserrat 2010). In 2012, over 770 sick or dead birds (plus several muskrats, Ondatra zibethicus) were found at PSSERPPI due to exposure to avian botulism and/or a microcystin-dominated HAB. Murphy et al. (2000) suggested that avian botulism can be triggered by HABs. Pathological analysis from the 2012 outbreak confirmed avian botulism in 6 of 17 birds; gut and liver samples from 14 birds, and 1 muskrat had microcystin concentrations (gut-50 to $1500 \mathrm{ppb}$; liver-79 to $6640 \mathrm{ppb}$ ) equal to or higher than those in other US HAB-associated bird and mammalian die-offs (L. Murphy, University of Pennsylvania, personal communication).

Eutrophication-driven hypoxia has increased in the world's coastal waters such that the number of anthropogenic anoxia sites grew from 195 in 1995 to over 400 in 2008 (Diaz and Rosenberg 2008; Rabalais et al. 2010). From 2000 through 2009 , hypoxia was observed in $26 \%$ of North Atlantic estuaries (including Great Bay, Narragansett Bay, and Long Island Sound) and 42\% of mid-Atlantic estuaries (Chesapeake Bay, and coastal waters of Delaware, New Jersey, and New York) (Committee on Environment and Natural Resources 2010). Many GCC-driven processes are likely to increase the extent and magnitude of coastal hypoxia (Figure 3) (Rabelais et al. 2010). In the Chesapeake Bay, greater stratification may result from the sea level rise-associated increased salinity of bottom waters (Kemp et al. 2009). Hypoxia-related mortality of fish, shellfish, and benthic macroinvertebrates would be expected to occur more often, because higher water temperatures have been linked to greater metabolic rates and $\mathrm{O}_{2}$ requirements (Breitburg 2002; Boesch et al. 2007). In addition to kills from acutely lethal conditions, chronic exposure to low and fluctuating $\mathrm{O}_{2}$ concentrations impair reproduction, immune responses, and growth of fish and invertebrates (Breitburg 2002). Concerns were expressed for Lake Champlain, where Stager and Thill (2010) projected that prolonged thermal 
stratification from increased surface water temperature would lead to greater deep-water hypoxia.

Laboratory studies documented that chronic exposure to hypoxia contributes to reproductive impairment in fish (Wu et al. 2003). Chronic exposure of carp (Cyprinus carpio) to $1 \mathrm{ppm}$ DO was associated with lower serum estradiol and testosterone concentrations, slower gonadal development, and diminished fertilization success, hatching rate, and larval survival. In field studies in Florida, young-of-the-year Atlantic croaker (Micropogonias undulatus) from hypoxic sites had impaired ovarian and testicular growth and lower androgens compared to those from normoxic sites (Thomas et al. 2007). Although published field studies in the NA LCC region could not be identified, similar effects may be occurring. Other concerns are that hypoxia may exacerbate the toxicity of PAHs in developing fish (an example of CITS) and that PCB exposure may hinder the ability of fish to respond to hypoxia (TICS) (Hooper et al. 2013).

\section{TAXA CASE STUDIES}

Here, we assess both direct GCC effects and GCCcontaminant/nutrient interactive effects on amphibians and mussels as examples of sensitive taxa. In addition to the 3 stressors discussed above, we include examples of interactive effects of GCC with pesticides and ionic pollutants, some of which may be associated with application of road salt.

\section{Amphibians}

Amphibian population declines and species extinctions are critical global issues. The major known causes are habitat loss, overexploitation, pollution, invasive species, and diseases such as chytridiomycosis (Stuart et al. 2004; Wake and Vredenburg 2008). Hoffman et al. (2010) reported that $41 \%$ of the world's amphibian species categorized on the International Union for the Conservation of Nature (IUCN) Red List are listed as threatened with extinction, the highest percentage of all vertebrate taxa. Amphibian occupancy rates in US habitats were surveyed from 2002 through 2011 (Adams et al. 2013), and decreases in both rare and common species were noted. Species in IUCN categories "near threatened" to "critically endangered" had mean occupancy rates decreasing at $11.6 \%$ per year, whereas those in "least concern" were decreasing at a lower but biologically relevant rate of $2.7 \%$ per year. There were no significant differences in the rate of decreases between regions of the US. According to Adams et al. (2013), GCC may be a contributing factor for the declines in amphibian occupancy combined with habitat loss, disease, and contaminants; effects due to GCC are subtle, however, and difficult to identify.

Within the northeast United States, several species of amphibians are of particular concern (NPARC 2010). Among anurans, 3 species, Carpenter's frog (Lithobates virgatipes), Eastern spadefoot (Scaphiopus holbrookii), and mountain chorus frog (Pseudacris brachyphona) are of special interest because they are found in more than $75 \%$ of the State Wildlife Action Plans (SWAPs) as species of concern; 4 others are of high concern because they are listed in $50 \%$ to $75 \%$ of the SWAPs. Among 6 species of caudates, the Jefferson salamander (Ambystoma jeffersonianum) is a species of high regional responsibility because northeastern states represent greater than $50 \%$ of its US and Canadian distribution. Five other salamanders are of high concern and 4 of moderate concern.
Amphibians are of particular interest for GCC impacts because their permeable skin and complex life cycle make them vulnerable to changes in temperature and precipitation that affect their aquatic and terrestrial habitats. Amphibians are ectothermic and might experience greater perturbations than endothermic birds and mammals. However, amphibians can maintain body temperatures within a few degrees via behavioral thermoregulation (Bicego et al. 2007).

In a recent review, Li et al. (2013) evaluated lethal and sublethal, direct and indirect, and positive as well as negative effects of GCC on amphibians. They concluded that there is little evidence of acute lethal effects, and data are inadequate to determine whether 3 "universal species responses" to global warming (e.g., changes in phenology [breeding dates]; shifts in geographic distributions; and reduced body size) are currently contributing to amphibian population declines. Li et al. (2013) stated that review of the interaction between climate and the prevalence of chytridiomycosis revealed more evidence for a causal link between temperature variability and the disease than between mean temperature and the disease.

GCC-contaminant interactions are complex and sometimes contradictory. For example, in laboratory tests with amphibians, toxicity of the carbamate insecticide carbaryl increased with water temperature (Boone and Bridges 1999), whereas there are examples of both greater and lesser toxicity at higher temperatures with pyrethroids (discussed by Materna et al. 1995). In nature, an additional consideration is the interaction between toxicity and exposure (Rohr et al. 2011). For some contaminants (e.g., atrazine) (Rohr and McCoy 2010), there are nonmonotonic concentration responses (i.e., changes in direction of response with changes in contaminant concentrations). Some studies on atrazine reported that exposure delayed metamorphosis, whereas others showed accelerated metamorphosis (Rohr and McCoy 2010). Such changes in the duration of the larval phase would affect toxic responses.

The increased seasonal drought and rising temperature predicted for the northeast US (Horton et al. 2014) may individually or in concert result in adverse effects on amphibians. Examples of such GCC-contaminant interactions are the Rohr and Palmer $(2005,2013)$ laboratory studies of the effects of temperature, desiccation, and sublethal atrazine exposure in streamside salamanders (Ambystoma barbouri), native to the Midwest United States. Findings indicated that exposure of larvae to atrazine decreased the adults' ability to resist desiccation some 8 months later. The species prefers cool $\left(\sim 22^{\circ} \mathrm{C}\right)$, moist conditions and uses behavioral adaptations such as huddling and decreased activity to survive warmer, dryer conditions. Despite these adaptations, there was loss of mass and greater mortality in salamanders exposed to $27^{\circ} \mathrm{C}$, a common summer temperature within their range (Rohr and Palmer 2013). Exposure to atrazine shortened time to death. Thus, behavioral adaptations did not fully compensate for exposure to prolonged adverse environmental conditions and atrazine exposure worsened the effects.

Salamanders could be negatively affected in the NA LCC region by GCC-related altered flow patterns of low-order streams and the hydrology of vernal wetlands. These sites tend to dry earlier than ponds favored by many anurans. An alternative possibility to GCC-induced adverse effects, however, is that increasing temperatures and nutrient loading may result in greater species richness in small temperate water bodies (Rosset et al. 2010). 
The current and future use of fertilizers and pesticides within the NA LCC region will be affected by economics, environmental regulations, and changes in the types and locations of farms. Warmer temperatures would result in longer growing seasons, differences in types of crops planted or livestock raised, increased use of groundwater, and changes in the quantity and types of fertilizers and pesticides applied (Wolfe et al. 2008). An additional concern is the interaction between nitrogenous compounds and pesticides. For example, Orton et al. (2006) reported that changes in sex ratios (favoring females) in northern leopard frogs (L. pipiens) were more marked in response to combined exposure to atrazine and nitrates than to these chemicals alone. At present, the net effect of these interacting factors cannot be predicted.

Two field studies addressed possible GCC-driven changes in the abundance of amphibians within the NA LCC region. Gibbs et al. (2005) compared population changes among 5 species of anurans in New York State between 1973 to 1980 and 2001 to 2002. They identified a net loss of roadside habitats, such as ditches, but no differences in population status among those habitats that still existed. At the local level, population declines were associated with acid deposition, urban development, forest cover, and agriculture. Although mean ambient temperatures in 2001 to 2002 were $0.26^{\circ} \mathrm{C}$ warmer than in 1973 to 1980, the difference was not statistically significant. Breeding phenologies for 4 amphibian species were slightly advanced in 2001 to 2002 compared to 1973 to 1980 . Whereas these changes might be ascribed to early evidence of GCC, Gibbs et al. (2005) did not consider climate to be a critical factor. Rather, they suggested that reductions in the amount of roadside habitat accounted for the decline in amphibian populations. Lowe (2012) found that populations of the stream salamander, Gyrinophilus porphyriticus, in New Hampshire decreased between 1999 and 2010. Based on linear regression, Lowe (2012) determined that the abundance of adults was negatively related to the amount of annual rainfall, which is predicted to increase in the Northeast (Hayhoe et al. 2007). Abundance was not significantly related to mean annual temperature. Lowe (2012) hypothesized that metamorphs may not be able to use flood-avoidance strategies used by larvae and adults, resulting in increased mortality.

\section{Freshwater mussels}

Freshwater mussel life history traits, such as dependency on specific host fish, environmentally sensitive larval and juvenile life stages, and their filter-feeding, benthic-dwelling biology, make mussels inherently vulnerable to natural and anthropogenic stressors (Neves et al. 1997; Strayer et al. 2004; Haag 2012). According to Williams et al. (1993) 213 (72\%) of the 297 species known in US waters are federal- or state-listed as endangered, threatened, or of special concern, making mussels one of the most imperiled animal groups in the country.

The river systems of the NA LCC region support 32 species of mussels. Included are 2 US-listed endangered species, dwarf wedgemussel (Alasmidonta heterodon) and James spinymussel (Pleurobema collina), and 1 candidate species, Atlantic pigtoe (Fusconaia masoni). The Connecticut River watershed in New England supports the largest known populations of the dwarf wedgemussel. The Penobscot River in Maine and rivers northward to New Brunswick, Canada and the Gulf of Saint Lawrence, support important populations of cool-cold water adapted mussel species such as the eastern pearlshell (Margaritifera margaritifera). This species is listed as critically imperiled in Pennsylvania (Pennsylvania Fish and Boat Commission 2011). The dwarf wedgemussel is listed as extirpated from its only recorded Canadian location within the Petitcodiac River drainage of New Brunswick. Two other species from Nova Scotia and New Brunswick, brook floater (Alasmidonta varicosa) and yellow lampmussel (Lampsilis cariosa), are listed by the provincial governments as species of special concern (New Brunswick 2014 Nova Scotia 2014). Both species are listed as threatened by Maine Department of Inland Fisheries and Wildlife (2014).

Stressors suspected as contributing to declines and extinctions of freshwater mussels occur at local, regional, and global scales. Locally, mussels suffer from habitat alteration (e.g., riparian clearing) that results in greater inputs of fine sediments, contaminants, and nutrients, and the impacts of invasive species. Regional scale stressors include river fragmentation and altered flow regimes, including dams that restrict movement of host fish. At the global scale, mussels suffer from direct and indirect GCC effects, including increased frequency of large floods and severe droughts, changes in stream and lake temperatures, losses of host fish populations, and increased salinization from shifts in human activities (Hastie et al. 2003; Galbraith et al. 2010).

Within the NA LCC region, GCC may affect freshwater mussel populations directly by altering stream temperatures or indirectly through increased loading of sediments, contaminants, and nutrients released from watersheds and stream banks during more frequent heavy storms. These alterations to aquatic systems could affect mussel host fishes, causing changes in their abundance and distribution. Kaushal et al. (2010) studied changes in river and stream temperatures by analyzing historical data in 40 rivers and streams across the United States. They reported significant temperature elevation in 20 rivers and streams (decreases in only 2) and concluded that the greatest increases were near urban areas in the midAtlantic states. Both climate change and urbanization, through increases in impervious surface area and loss of riparian areas and canopy cover contribute to the temperature responses. Laboratory studies demonstrated that juvenile and adult mussels in US streams had reduced growth and high mortality at water temperatures of greater than or equal to 32 to $34^{\circ} \mathrm{C}$ (Pandolfo et al. 2010; Carey et al. 2013). In laboratory tests with 3 species native to the Midwest and southeastern United States, lethal temperatures affecting $50 \%$ of the test group ranged from 25.3 to $30.3{ }^{\circ} \mathrm{C}$ (Ganser et al. 2013). Thus, some freshwater mussel species may already be living close to their upper thermal tolerances (Pandolfo et al. 2010), and recent rises in stream temperatures have already resulted in shifting species abundance toward those with greater thermal tolerance (Galbraith et al. 2010).

Mussels are particularly sensitive to ammonia (Strayer and Malcom 2012; USEPA 2013b). Natural sources of ammonia in the environment include excretion of nitrogenous wastes by animals, decay of animal and plant matter, and fixation by bacteria. Anthropogenic sources include wastewater treatment plant effluent, releases from septic systems, runoff of nitrogenous fertilizers from crops, runoff of animal wastes from feedlots and grazing pastures, and industrial processes such as production of cleaning products and fertilizers. The USEPA (2013b) ammonia criteria for freshwater was recently lowered from previous values, based on new data that indicated that the 7 most sensitive genera were freshwater mussels. Ammonia is more harmful to juvenile and adult mussels in the summer, 
when water levels are low and temperatures high. Elevated temperatures documented and predicted with GCC result in a greater fraction of ammonia existing in the toxic un-ionized form $\left(\mathrm{NH}_{3}\right)$ (USEPA 2013b). Furthermore, ammonia can reach higher concentrations in interstitial porewater of stream substrates compared with overlying water (Frazier et al. 1996). Strayer (2013) stated that concentrations of interstitial $\mathrm{NH}_{3}$ may rise when $\mathrm{DO}$ is low and loadings of reactive $\mathrm{N}$ are high.

Strayer and Malcom (2012) concluded that $\mathrm{NH}_{3}$ was the primary cause of recruitment failure of the eastern elliptio (Elliptio complanata) in southeastern New York. They tested whether interstitial $\mathrm{NH}_{3}$ concentrations differed between sites with recruiting populations versus those with nonrecruiting populations. They also tested whether sites differed with respect to fine sediments, interstitial DO, crayfish densities, or presence of American eels (Anguilla rostrata), a host species. A relationship with interstitial $\mathrm{NH}_{3}$ concentrations was found; a threshold of $0.2 \mu \mathrm{g} / \mathrm{L}$ separated recruiting from failing populations. The authors postulated that $\mathrm{NH}_{3}$ poses a threat to many mussel species over broad regions of the world.

According to Kaushal et al. (2005) baseline stream salinities are increasing within areas of the NA LCC toward thresholds beyond which ecological communities and ecosystem functions might not recover. Stream salinization refers to an increase in the concentration of total dissolved solids in water and can be detected by increases in ionic pollutants that are acutely toxic to freshwater mussels such as $\mathrm{Cl}^{-}, \mathrm{Na}^{+}, \mathrm{K}^{+}$, $\mathrm{Mn}^{+2}$, and $\mathrm{SO}_{4}^{-}$(Echols et al. 2009; Gillis 2011). In recent decades, increasing percentages of land use as roads and other impervious surfaces has been associated with sharp increases in concentrations of $\mathrm{Na}^{+}$and $\mathrm{Cl}^{-}$in aquatic systems, primarily due to the use of road salt (Kaushal et al. 2005; Environment Canada 2012). $\mathrm{Cl}^{-}$concentrations in surface waters were elevated substantial distances from roadways due to gradual releases from groundwater, leading to widespread adverse impacts on water quality.

Many parts of Canada have experienced changes to their winter climate over the past decade (Environment Canada 2012). These changes include more freeze-thaw cycles, more frequent and larger storms, freezing rain, and longer periods when temperatures are within the working temperature of salt. Such changes can lead to more winter maintenance activities including greater road salt application. However, Mills and Andrey (2002) stated that empirical relationships between temperature and historic rates of salt use suggest that a warming of 3 to $4{ }^{\circ} \mathrm{C}$ could decrease salt and sand use by $20 \%$ to $70 \%$. An additional impact of GCC is the increased number and duration of droughts resulting in reduced flow and higher $\mathrm{Cl}^{-}$concentrations. Clearly, GCC is one of many factors potentially affecting stream salinization, but there is uncertainty regarding the magnitude and direction of impact.

Hence, a future with greater incidence of drought and accompanying higher temperatures, low flows, and salt and ammonia toxicity in streams may prove stressful for many mussel species within the NA LCC region. For example, the preferred habitat of the dwarf wedgemussel is clear, cool, and relatively small streams with abundant sand and small gravel substrate (Michaelson and Neves 1995). Such habitats are vulnerable to excessive ammonia and salt inputs from agriculture, wastewater, road runoff, and shifts in hydrology, and to higher temperatures.

\section{SUMMARY AND RESEARCH RECOMMENDATIONS}

For each case study, we summarize key findings and highlight areas requiring additional research. Based on the overarching concern for natural resources in the NA LCC and the need for approaches that provide utility for land and resource managers, we suggest research topics based on the following criteria: 1) whether the results will enhance our understanding of the impacts of these GCC-related stressors on natural resources, especially species of concern; 2) whether the findings can be applied to lead to a reduction of threats driving population losses of threatened and endangered species, certain interjurisdictional fishes, migratory birds, amphibians, and freshwater mussels; and 3) whether the results will reduce uncertainty related to prudent natural resource management.

\section{Stressors}

The NA LCC region includes ecosystems sensitive to $\mathrm{Hg}$ deposition. Several bird species of high conservation status have $\mathrm{Hg}$ body burdens associated with reduced nesting success. We recommend research on the interactive effects of GCC (including changing requirements for water level management of impoundments) on generation and bioavailability of $\mathrm{MeHg}$, and the effects of GCC-driven shifts in species distributions on $\mathrm{MeHg}$ exposure.

Freshwater acidification has adversely affected terrestrial and aquatic ecosystems in high elevation areas of New York (Adirondacks), New England, and the Maritimes that are slowly recovering due to decreased emissions of $\mathrm{N}$ and sulfur oxides. Research is needed on how GCC will affect that recovery. A byproduct of decreases in acid deposition is enhanced mobilization of dissolved organic matter. Increases in dissolved organic carbon coupled with GCC may alter endpoints of acidification recovery through shifts in biological communities and also affect $\mathrm{Hg}$ dynamics (see above). Research is needed to understand how GCC concurrent with decreased acid deposition will alter the structure and function of acid-sensitive watersheds and surface waters.

Eutrophication in many estuaries in the NA LCC region is projected to increase due to greater runoff from watersheds receiving heavier storms and less denitrification in riparian wetlands. Hypoxia in the Chesapeake Bay and other estuaries may be exacerbated by increased stratification. Elevated water temperature favors algal species that produce HABs associated with bird die-offs. Research is needed on the effects of GCC on HABs and avian disease, and how more severe and extensive hypoxia events will affect fish and shellfish populations.

Information should be compiled for other contaminants exhibiting widespread exposure and known toxicity within various NA LCC ecoregions. A priority would be PCBs and legacy organochlorine contaminants that are risk drivers for fish consumption advisories throughout the region. Additional information should be gathered on GCC-contaminant interactions of current use pesticides, PAHs, and endocrine disrupting compounds.

\section{Taxa}

Amphibian populations appear to be declining and several northeastern species are of special concern. Information is needed on 1) thermal tolerance and moisture needs of species of concern; 2) effects of multiple stressors (temperature, desiccation, contaminants, nutrients); and 3) the feasibility of approaches to mitigate GCC-related stressors of increased 
temperature and seasonal drought, such as manipulation of water levels and providing shelter and canopy cover.

GCC may affect freshwater mussel populations via altered stream temperatures or through increased sediment, contaminant, and nutrient loading from more frequent heavy storms. Freshwater mussels are extremely sensitive to un-ionized ammonia that is more toxic at higher temperatures. The extent to which GCC will exacerbate exposure of mussels to unionized ammonia, greater runoff, and reduced porewater DO is unknown. We recommend research to identify mussel species and populations that are vulnerable and those that are resilient to rising stream temperatures, hydrologic shifts, and ionic pollutants, all of which are influenced by GCC.

Scientists should continue to gather information on direct and indirect GCC-related threats to plants, invertebrates, fishes, birds, and mammals identified as priority species by the NA LCC (USFWS 2009) and by other conservation partnerships. This case study approach is applicable to agencies and NGOs working in other geographic areas, and is especially relevant for the other 21 LCCs across North America.

Acknowledgment-We appreciate the support of the US Fish and Wildlife Service Northeast Region Science Applications Program. Comments from Tom Augspurger (USFWS), Peter Murdoch (USGS), and Bruce Stein (National Wildlife Federation), the journal reviewers, and editor are appreciated.

Disclaimer-The findings and conclusions in this article are those of the authors and do not necessarily represent the views of the US Fish and Wildlife Service or US Geological Survey.

\section{REFERENCES}

Adams MJ, Miller DAW, Muths E, Corn PS, Grant EHC, Bailey LL, Fellers GM, Fisher RN, Sadinski WJ, Waddle H, et al. 2013. Trends in amphibian occupancy in the United States. PLOS One 8:e64347.

Armado LL, Monserrat JM. 2010. Oxidative stress generation by microcystins in aquatic animals: Why and how. Environ Int 36:226-235.

Baker JP, Van Sickle J, Gagen CJ, DeWalle DR, Sharpe WE, Carline RF, Baldigo BP, Murdoch PS, Bath DW, Kretser WA, et al. 1996. Episodic acidification of small streams in the northeastern United States: Effects on fish populations. Ecol App/ 6:422-437.

Balayla D, Lauridsen TL, Søndergaard M, Jeppesen E. 2010. Larger zooplankton in Danish lakes after cold winters: Are winter fish kills of importance? Hydrobiologia 646:159-172.

Bergeron CM, Husak JF, Unrine JM, Romanek CS, Hopkins WA. 2007. Influence of feeding ecology on blood mercury concentrations in four species of turtles. Environ Toxicol Chem 26:1733-1741.

Bergeron CM, Hopkins WA, Todd BD, Hepner MJ, Unrine JM. 2011. Interactive effects of maternal and dietary mercury exposure have latent and lethal consequences for amphibian larvae. Environ Sci Technol 45:37813787.

Bicego KC, Barros RCH, Bracno LGS. 2007. Physiology of temperature regulation: Comparative aspects. Comp Biochem Physiol Part A: Molec Integ Physiol 147:616-639.

Boesch DF, Coles VJ, Kimmel DG, Miller WD. 2007. Coastal dead zones and global climate change: ramifications of climate change for Chesapeake Bay hypoxia. Arlington (VA): Pew Center on Global Climate Change. [cited 2014 March 17]. Available from: http://www.c2es.org/docUploads/Regional-Impacts-Chesapeake.pdf

Boone MD, Bridges CM., 1999. The effect of temperature on the potency of carbaryl for survival of tadpoles of the green frog (Rana clamitans). Environ Toxicol Chem 18:1482-1484.

Breitburg DL., 2002. Effects of hypoxia, and the balance between hypoxia and enrichment on coastal fishes and fisheries. Estuaries 25:767-781.

Burgess NM, Meyer MW. 2008. Methylmercury exposure associated with reduced productivity in common loons. Ecotoxicology 17:83-91.
Carey CC, Ibelings BW, Hoffmann EP, Hamilton DP, Brookes JD. 2012. Ecophysiological adaptations that favour freshwater cyanobacteria in a changing climate. Water Res 46:1394-1407.

Carey CS, Jones JW, Butler RS, Hallerman EM. 2013. Determining optimum temperature for growth and survival of laboratory-propagated juvenile freshwater mussels. N Am J Aquacul 75:532-542.

Carmichael WW. 1994. The toxins of cyanobacteria. Sci Am 270:78-86.

[CCME] Canadian Council of Ministers of the Environment. 2000. Canadian tissue residue guidelines for the protection of wildlife consumers of aquatic biota: Methylmercury. Winnipeg (MB): CCME.

Chaplin SJ, Gerrard RA, Watson HM, Master LL, Flack SR. 2000. The geography of imperilment: Targeting conservation toward critical biodiversity areas. In: Stein BA, Kutner LS, Adams JS, editors. Precious heritage. The status of biodiversity in the United States. Oxford (UK): Oxford Univ Press. p 159-199.

Chen CW, Gherini SA, Peters NE, Murdoch PS, Newton RM, Goldstein RA. 1984. Hydrological analysis of acidic and alkaline lakes. Water Resources Res 20:1875-1882.

Chen CY, Dionne M, Mayes B, Ward D, Sturup S, Jackson B., 2009. Mercury bioavailability and bioaccumulation in estuarine food webs in the Gulf of Maine. Environ Sci Technol 43:1804-1810.

Chen CY, Driscoll CT, Kamman NC. 2012. Mercury hotspots in freshwater ecosystems: Drivers, processes, and patterns. In: Bank MS, editor. Mercury in the environment: Pattern and process. Berkeley (CA): Univ of California Press. $p$ 143-166.

Codd GA. 1995. Cyanobacterial toxins: occurrence, properties, and biological significance. Water Sci Technol 32:149-156.

Committee on Environment and Natural Resources. 2010. Scientific assessment of hypoxia in U.S. Coastal Waters. Washington (DC): Interagency Working Group on Harmful Algal Blooms, Hypoxia, and Human Health of the Joint Subcommittee on Ocean Science and Technology. [cited 201417 March]. Available from: http://www.whitehouse.gov/sites/default/files/microsites/ ostp/hypoxia-report.pdf

Coristine LE, Kerr JT. 2011. Habitat loss, climate change, and emerging conservation challenges in Canada. Can J Zool 89:435-451.

Depew DC, Basu N, Burgess NM, Campbell LM, Evers DC, Grasman KA, Kenow KP, Meyer MW, Scheuhammer AM, Williams K. 2012. Derivation of screening benchmarks for the common loon (Gavia immer) for dietary methylmercury (MeHg): Justification and rationale for use in ecological risk assessment. Environ Toxicol Chem 31:2399-2407.

Diaz RJ, Rosenberg R. 2008. Spreading dead zones and consequences for marine ecosystems. Science 321:926-929.

Dijkstra JA, Buckman KL, Ward D, Evans DW, Dionne M, Chen CY. 2013. Experimental and natural warming elevates mercury concentrations in estuarine fish. PLOS ONE 8:e58401.

Driscoll CT, Newton RM, Gubala CP, Baker JP, Christensen SW., 1991. Adirondack Mountains. In: Charles DF editor. Acidic deposition and aquatic ecosystems: Regional case studies. New York: Springer-Verlag. p 133-202.

Driscoll C, Whitall D, Aber J, Boyer E, Castro M, Cronan C, Goodale C, Groffman P, Hopkinson C, Lambert K, et al.. 2003. Nitrogen pollution: Sources and consequences in the US Northeast. Environment 45:8-23.

Driscoll CT, Driscoll KM, Roy KM, Dukett J. 2007. Changes in the chemistry of lakes in the Adirondack region of New York following declines in acidic deposition. App/ Geochem 22:1181-1188.

Driscoll CT, Han Y-J, Chen CY, Evers DC, Lambert KF, Holsen TM, Kamman NC, Munson RK. 2007. Mercury contamination in forest and freshwater ecosystems in the Northeastern United States. BioScience 57:17-28.

Driscoll CT, Lawrence GB, Bulger AJ, Butler TJ, Cronan CS, Eagar C, Lambert KF, Likens GE, Stoddard JL, Weathers KC. 2001. Acidic deposition in the northeastern United States: Sources and inputs, ecosystem effects, and management strategies. BioScience 51:180-198.

Driscoll CT, Mason RP, Chan HM, Jacob DJ, Pirrone N. 2013. Mercury as a global pollutant: Sources, pathways, and effects. Environ Sci Technol 47:4967-4983.

Echols BS, Currie RJ, Cherry DS. 2009. Influence of conductivity dissipation on benthic macroinvertebrates in the North Fork Holston River, Virginia downstream of a point source brine discharge during severe low-flow conditions. Hum Ecol Risk Assess 15:170-184.

Edmonds ST, Evers DC, O'Driscoll NJ, Mettke-Hoffman C, Powell L, Cristol D, McGann AJ, Armiger JW, Lane O, Tessler DF, et al.. 2010. Geographic and 
seasonal variation in mercury exposure of the declining Rusty Blackbird. Condor 112:789-799.

Environment Canada. 2012. Five-year review of progress: Code of practice for the environmental management of road salts. Gatineau (QC): Environment Canada. [cited 2014 March 17]. Available from: http://www.ec.gc.ca/selssalts/45D464B1-96CC-4A27-8B96-42224F3C3CD5/COM1481_five_year_Code_E-_v3.pdf

Evers DC, Burgess N, Champoux L, Hoskins B, Major A, Goodale W, Taylor R, Poppenga R, Daigle T. 2005. Patterns and interpretation of mercury exposure in freshwater avian communities in northeastern North America. Ecotoxicology 14:193-222.

Evers DC, Han Y-J, Driscoll CT, Kamman NC, Goodale WM, Lambert KF, Holsen TM, Chen CY, Clair TA, Butler T. 2007. Biological mercury hotspots in the Northeastern United States and Southeastern Canada. BioScience 57: $1-15$.

Evers DC, Jackson AK, Tear TH, Osborne CE., 2011. Hidden risk: Mercury in terrestrial ecosystems of the Northeast. Gorham (ME): Biodiversity Research Institute. $33 \mathrm{p}$.

Evers DC, Savoy L, DeSorbo CR, Yates D, Hanson W, Taylor KM, Siegel L, Cooley JH, Bank M, Major A, et al.. 2008. Adverse effects from environmental mercury loads on breeding common loons. Ecotoxicology 17:69-81.

Fakhraei H, Driscoll CT, Selvendiran P, DePinto JV, Bloomfield J, Quinn S, Rowell C., 2014. Development of a total maximum daily load (TMDL) for acid-impaired lakes in the Adirondack region of New York. Atmos Environ 95:277-287.

Falconer IR., 2005. Cyanobacterial toxins of drinking water supplies. New York: CRC. 279 p.

Frazier BE, Naimo TJ, Sandheinrich MB. 1996. Temporal and vertical distribution of total ammonia nitrogen and un-ionized ammonia nitrogen in sediment pore water from the upper Mississippi River. Environ Toxicol Chem 15:92-99.

Frumhoff PC, Mcarthy JJ, Melillo JM, Moser SC, Wuebbles DJ. 2007. Confronting climate change in the U.S. Northeast. Science, impacts, and solutions. Synthesis report of the Northeast Climate Impacts Assessment (NECIA). Cambridge (MA): Union of Concerned Scientists.

Galbraith HS, Spooner DE, Vaughn CC. 2010. Synergistic effects of regional climate patterns and local water management on freshwater mussel communities. Biol Conserv 143:1175-1183.

Ganser AM, Newton TJ, Haro RJ. 2013. The effects of elevated water temperature on native juvenile mussels: Implications for climate change. Freshwat Sci 32:1168-1177.

Gibbs JP, Whiteleather KK, Schueller FW. 2005. Changes in frog and toad populations over 30 years in New York State. Ecol App/ 15:1148-1157.

Gillis PL. 2011. Assessing the toxicity of sodium chloride to the glochidia of freshwater mussels: Implications for salinization of surface waters. Environ Pollut 159:1702-1708

Gobler CJ, Sunda WG. 2012. Ecosystem disruptive algal blooms of the brown tide species, Aureococcus anophagefferens and Aureoumbra laguninsis. Harmful Algae 14:36-45.

Gobler C, Berry DL, Anderson OR, Burson A, Koch F, Rogers BS, Moore LK, Goleski JA, Allam B, Bowser P, et al. 2008. Characterization, dynamics, and ecological impacts of harmful Cochlodinium polykrikoides blooms on eastern Long Island, NY, USA. Harmful Algae 7:293-307.

Goshorn D, Deeds J, Tango P, Poukish C, Place A, McGinty M, Butler W, Luckett C, Magnien R. 2004. Occurrence of Karlod in ium micrum and its association with fish kills in Maryland estuaries. In: Steidinger KA, Landsberg $J H_{\text {, Tomas } C R}$ Vargo GA, editors. Harmful algae 2002. Florida Fish and Conservation Commission, UNESCO. p 361-363.

Groffman PM, Rustad LE, Templer PH, Campbell JL, Christenson LM, Lany NK, Socci AM, Vadeboncoeur MA, Schaberg PG, Wilson GF, et al. 2012. Long-term integrated studies show complex and surprising effects of climate change in the northern hardwood forest. BioScience 62:1056-1066.

Haag WR., 2012. North American freshwater mussels: natural history, ecology, and conservation. New York (NY): Cambridge Univ Press. 505 p.

Hallinger KK, Cristol DA., 2011. The role of weather in mediating the effect of mercury exposure on reproductive success in tress swallows. Ecotoxicology 20:1368-1377.

Hastie LC, Cosgrove PJ, Ellis N, Gaywood MJ., 2003. The threat of climate change to freshwater pearl mussel populations. Ambio 32:40-46.

Hayhoe K, Wake CP, Huntington TG, Luo L, Schwartz MD, Sheffield J, Wood E, Anderson B, Bradbury J, DeGaetano A, et al. 2007. Past and future changes in climate and hydrological indicators in the US Northeast. Climate Dynam 28:381-407.

Hoffman M, Hilton-Taylor C, Angulo A, Bohm M, Brooks TM, Butchart SHM, Carpenter KE, Chanson J, Collen B, Cox NA, et al. 2010. The impact of conservation on the status of the world's vertebrates. Science 330:1503-1509.

Hooper MJ, Ankley G, Cristol DE, Maryoung L, Noyes P, Pinkerton K. 2013. Interactions between chemical and climate stressors: A role for mechanistic toxicology in assessing climate change risks. Environ Toxicol Chem 32:32-48. Horton RG, Yohe G, Easterling W, Kates R, Ruth M, Sussman E, Whelchel A, Wolfe D, Lipschultz F., 2014. Northeast. In: Melillo JM, Richmond TC, Yohe GW, editors. Climate change impacts in the United States: The third national climate assessment. US Global Change Research Program. p 371-395. [cited 2014 December 2]. Available from: http://nca2014.globalchange.gov/ report/regions/northeast

Howarth RW, Swaney DP, Boyer EW, Marino R, Jaworski N, Goodale C., 2006. The influence of climate on average nitrogen export from large watersheds in the Northeastern United States. Biogeochemistry 79:163-186.

[IPCC] Intergovernmental Panel on Climate Change. 2007. A report of working group I of the intergovernmental panel on climate change. Summary for policymakers and technical summary. [cited 2014 March 17]. Available from: http://www.ipcc.ch/publications_and_data/ar4/wg1/en/spm.html

Jackson AK, Evers DC, Etterson MA, Condon AM, Folsom SB, Detweiler J, Schmerfeld J, Cristol DA. 2011. Mercury exposure affects the reproductive success of a free-living songbird, the Carolina Wren. Auk 128:759-769.

Kamman NC, Burgess NM, Driscoll CT, Simonin HA, Goodale W, Linehan J, Estabrook R, Hutcheson M, Major A, Scheuhammer AM, et al. 2005. Mercury in freshwater fish of northeast North America-A geographic perspective based on fish tissue monitoring databases. Ecotoxicology 14:163-180.

Kaushal SS, Groffman PM, Likens GE, Belt KT, Stack WP, Kelly VR, Band LE, Fisher GT. 2005. Increased salinization of fresh water in the northeastern United States. Proc Nat Acad Sci USA 102:13517-13520.

Kaushal SS, Likens GE, Jaworski NA, Pace ML, Sides AM, Seekell D, Belt KT, Secor DH, Wingate RL. 2010. Rising stream and river temperatures in the United States. Ecol Environ 8:461-466.

Kemp WM, Testa JM, Conley DJ, Gilbert D, Hagy JD. 2009. Temporal responses of coastal hypoxia to nutrient loading and physical controls. Biogeoscience 6:2985-3008.

Kuiper-Goodman T, Falconer I, Fitzgerald J. 1999. Chapter 4. Human health aspects. In: Chorus I, Bartram J, editors. Toxic cyanobacteria in water: A guide to their public health consequences, monitoring, and management. E \& FN Spon on behalf of WHO. London. p 113-153. London (UK): UNESCO.

Lake Champlain Basin Program. 2012. State of the Lake and ecosystem indicators report. Grande Isle (VT): Lake Champlain Basin Program. [cited 2014 March 17]. Available from: http://sol.lcbp.org/introduction what-is-state-of-lake-report.html

Landis WG, Durda J, Brooks ML, Chapman PM, Menzie CA, Stahl RG Jr, Stauber JL. 2013. Ecological risk assessment in the context of global climate change. Environ Toxicol Chem 32:79-92.

Lane OP, O'Brien KM, Evers DC, Hodgman TP, Major A, Pau N, Ducey MJ, Taylor R, Perry D. 2011. Mercury in breeding saltmarsh sparrows (Ammodramus caudacutus). Ecotoxicology 20:1984-1991.

Lavoie RA, Jardine TD, Chumchal MM, Kidd KA, Campbell LM. 2013. Biomagnification of mercury in aquatic food webs: A worldwide metaanalysis. Environ Sci Technol 47:13385-13394.

Lemmen DS, Warren EJ, Lacroix J, Bush E, editors. 2008. From impacts to adaptation: Canada in a changing climate 2007. Ottawa (ON): Government of Canada. 448 p.

Li Y, Cohen JM, Rohr, JR. 2013. Review and synthesis of the effects of climate change on amphibians. Integr Zool 8:145-161.

Lowe WH. 2012. Climate change is linked to long-term decline in a stream salamander. Biol Conserv 145:48-53.

Lürling M, Eshetu F, Faassen EJ, Kosten S, Huszar VLM. 2013. Comparison of cyyanobacterial and green algal growth rates at different temperatures. Freshwater Biol 58:552-559.

Maine Department of Inland Fisheries and Wildlife. 2014. State list of endangered and threatened species. [cited 2014 April 17]. Available from: http://www. maine.gov/ifw/wildlife/endangered/listed_species_me.htm

Marshall HG. 2013. Phytoplankton in Virginia lakes and reservoirs. Virginia J Sci 64:3-15. 
Marshall HG, Egerton TA. 2009a. Increasing occurrence and development of potentially harmful algal blooms in Virginia tidal rivers. In: Conference Proceedings, Water Resources in Changing Climates, Virginia Water Research Conference, 2009 Oct 15-16; Richmond, VA. p 89-101.

Marshall HG, Egerton TA. 2009b. Phytoplankton blooms: Their occurrence and composition within Virginia's tidal tributaries. Virginia J Sci 60:149-164.

Marshall HG, Lane M, Nesius K, Burchardt L. 2009. Assessment and significance of phytoplankton species composition within Chesapeake Bay and Virginia tributaries through a long-term monitoring program. Environ Monit Assess 150:143-155.

Materna EJ, Rabeni CF, LaPoint TW. 1995. Effects of the synthetic pyrethroid insecticide, esfenvalerate, on larval leopard frogs (Rana spp.). Environ Toxicol Chem 14:613-622

Melillo JM, Richmond TC, Yohe GW, editors. 2014. Climate change impacts in the United States: The third national climate assessment. US Global Change Research Program. 841 p. [cited 2014 December 2]. Available from: http:// nc2014.globalchange.gov

Michaelson DL, Neves RJ. 1995. Life history and habitat of the endangered dwarf wedgemussel Alasmidonta heterodon (Bivalvia:Unionidae). I N Am Benthol Soc 14:324-340.

Mills B, Andrey J. 2002. Climate change and transportation: Potential interactions and impacts. In: The potential impacts of climate change on transportation. Federal Research Partnership Workshop, October 1-2, 2002, Summary and Discussion Papers. Washington DC: US Department of Transportation. p 7788. [cited 2014 March 17]. Available from: http://www.climate.dot.gov/ documents/workshop1002/mills.pdf

Moe J, de Schamphelaere K, Clements WH, Sorensen M, van den Brink P, Liess M. 2013. Combined and interactive effects of global climate change and toxicants on populations and communities. Environ Toxicol Chem 32:49-61.

Murdoch PS, Stoddard JL. 1992. The role of nitrate in the acidification of streams in the Catskill Mountains of New York. Water Resour Res 28:27072720.

Murphy T, Lawson A, Nalewajko C, Murkin H, Ross L, Oguma K, McIntyre T. 2000. Algal toxins-Initiators of avian botulism? Environ Toxicol 15:558-567.

Najjar RG, Pyke CR, Adams MB, Breitburg D, Hershner C, Kemp M, Howarth R, Mulholland MR, Paolisso M, Secor D, et al. 2010. Potential climate-change impacts on the Chesapeake Bay. Estuar Coast Shelf Sci 86:1-20.

Neves RJ, Bogan AE, Williams JD, Ahlstedt SA, Hartfield PW. 1997. Status of aquatic mollusks in the southeastern United States A downward spiral of diversity. In: Benz GW, Collins DE, editors. Aquatic fauna in peril: The southeastern perspective. Special Publication 1. Decatur (GA): Southeast Aquatic Research Institute Lenz Design \& Communications. p 43-85.

New Brunswick. 2014. Natural resources. Species at risk public registry: Molluscs. [cited 2014 April 17]. Available from: http://www1.gnb.ca/0078/SpeciesAtRisk/results-e.asp

Nobis Engineering. 2008. Final supplemental baseline ecological risk assessment. Nyanza OU4 Chemical Waste Dump Superfund Site Operable Unit 4-Sudbury River Ashland, Massachusetts. Concord (MA): Nobis Engineering. [cited 2014 December 2]. Available from: http://www.epa.gov/region1/superfund/sites/ nyanza/443220.pdf

[NEPARC] Northeast Partners in Amphibian and Reptile Conservation. 2010. Northeast Amphibian and Reptile Species of Regional Responsibility and Conservation. NEPARC. Publication 2010-1. [cited 2014 March 17]. Available from: http://www.northeastparc.org/products/pdfs/NEPARC NEspeciesofresponsibility.pdf

Nova Scotia. 2014. Species at Risk Overview. NS Endangered Species Act: Legally listed species. [cited 2014 April 17]. Available from: http://novascotia.ca/natr/ wildlife/biodiversity/species-list.asp

Noyes PD, McElwee MK, Miller HD, Clark BW, Van Tiem LA, Walcott KC, Erwin KN, Levin ED., 2009. The toxicology of climate change: Environmental contaminants in a warming world. Environ Int 35:971-986.

O'Neil JM, Davis TW, Burford MA, Gobler CJ. 2012. The rise of harmful cyanobacteria blooms: The potential roles of eutrophication and climate change. Harmful Algae 14:313-334.

Orton F, Carr JA, Handy RD. 2006. Effects of nitrate and atrazine on larval development and sexual differentiation in the northern leopard frog Rana pipiens. Environ Toxicol Chem 25:65-71.

Paerl HW, Huisman J. 2009. Climate change: A catalyst for global expansion of harmful cyanobacterial blooms. Environ Microbiol Repts 1:27-37.
Pandolfo TJ, Cope WG, Arellano C, Bringolf RB, Barnhart MC, Hammer E. 2010. Upper thermal tolerances of early life stages of freshwater mussels. J N Am Benthol Soc 29:959-969.

Pennsylvania Fish and Boat Commission. 2011. Species action plan: Eastern pearlshell (Margaritifera margaritifera). Harrisburg (PA): Pennsylvania Fish and Boat Commission. $10 \mathrm{p}$.

Pourmokhtarian A, Driscoll CT, Campbell JL, Hayhoe K. 2012. Modeling potential hydrochemical responses to climate change and rising $\mathrm{CO}_{2}$ at the Hubbard Brook Experimental Forest using a dynamic biogeochemical model (PnETBGC). Water Resources Res 48:W07514.

Prasad MBK, Long W, Zhang X, Wood RJ, Murtugudde R. 2011. Predicting dissolved oxygen in the Chesapeake Bay: Applications and implications. Aquatic Sci 73:437-451.

Rabalais NN, Turner RE, Diaz RJ, Justic D. 2009. Global change and eutrophication of coastal waters. ICES J Mar Sci 66:1528-1537.

Rabalais NN, Cai W-J, Carstensen J, Conley DJ, Fry B, Quiñones-Rivera X, Rosenberg $R$, Slomp CP, Turner RE, Voss M, et al. 2014. Eutrophication-driven deoxygenation in the coastal ocean. Oceanography 70:123-133.

Rabalais NN, Diaz RJ, Levin LA, Turner RE, Gilbert D, Zhang J. 2010. Dynamics and distribution of natural and human-caused hypoxia. Biogeoscience 7:585-619.

Rohr JR, Johnson P, Hickey CW, Helm RC, Fritz AR, Brasfield S. 2013. Implications of global climate change for natural resource damage assessment, restoration, and rehabilitation. Environ Toxicol Chem 32:93-101.

Rohr JR, McCoy KA. 2010. A qualitative meta-analysis reveals consistent effects of atrazine on freshwater fish and amphibians. Environ Health Perspect 118:2032.

Rohr JR, Palmer BD. 2005. Aquatic herbicide exposure increases salamander dessication risk eight months later in a terrestrial environment. Environ Toxicol Chem 24:1253-1258.

Rohr JR, Palmer BD. 2013. Climate change, multiple stressors, and the decline of ectotherms. Conserv Biol 27:741-751.

Rohr JR, Sesterhenn TM, Stieha C. 2011. Will climate change reduce the effects of a pesticide on amphibians?: Partitioning effects on exposure and susceptibility to contaminants. Global Change Biol 17:657-666.

Rosset V, Lehmann A, Oertili B. 2010. Warmer and richer? Predicting the impact of climate warming on species richness in small temperate waterbodies. Global Change Biol 16:2376-2387.

Salazar K. 2010. Addressing the impacts of climate change on America's water, land, and other natural and cultural resources. Order No. 3289, Amendment No. 1. Washington DC: Department of the Interior.

Sandheinrich MB, Wiener JG. 2011. Methylmercury in freshwater fish: Recent advances in assessing toxicity of environmentally relevant exposures. In: Beyer WN, Meador JP, editors. Environmental contaminants in biota. 2nd ed. Boca Raton (FL): CRC. p 169-190.

Schiedek D, Sundelin B, Readman JW, Macdonald RW. 2007. Interactions between climate change and contaminants. Mar Pollut Bull 54:1845-1856.

Schmeltz D, Evers DC, Driscoll CT, Artz R, Cohen M, Gay D, Haeuber R, Krabbenhoft DP, Mason R, Morris K, et al. 2011. MercNet: A national monitoring network to assess repsonses to changing mercury emissions in the United States. Ecotoxicology 20:1713-1725.

Selvendiran P, Driscoll CT, Bushey JT Montesdeoca MR. 2008. Wetland influence on mercury fate and transport in a temperate forested watershed. Environ Pollut 154:46-55.

Shore RF, Pereira MG, Walker LA, Thompson DR. 2011. Mercury in nonmarine birds and mammals. In: Beyer WN, Meador JP, editors. Environmental contaminants in biota. 2nd ed. Boca Raton (FL): CRC. p 609-624.

Smithwick EAH, Eissenstat DM, Lovett GM, Bowden RD, Rustad LE, Driscoll CT. 2013. Root stress and nitrogen deposition: Consequences and research priorities. New Phytol 197:712-719.

Sparling DW, Linder G, Bishop CA, Krest S, editors. 2010. Ecotoxicology of amphibians and reptiles. 2nd ed. Boca Raton (FL): CRC. 916 p.

Stager JC, Thill M. 2010. Climate change in the Champlain basin. What natural resource managers can expect and do. Keene Valley (NY): The Nature Conservancy.

Stahl RG Jr, Hooper MJ, Balbus JM, Clements W, Fritz A, Gouin T, Helm R, Hickey C, Landis W, Moe SJ. 2013. The influence of global climate change on the scientific foundations and applications of environmental toxicology and chemistry: Introduction to a SETAC international workshop. Environ Toxicol Chem 32:13-19. 
Staudt A, Leidner AK, Howard J, Brauman KA, Dukes JS, Hansen U, Paukert C, Sabo J, Solorzano LA. 2013. The added complications of climate change: Understanding and managing biodiversity and ecosystems. Front Ecol Environ 11:494-501.

Stoddard JL, Jeffries DS, Lukewille A, Clair TA, Dillon PJ, Driscoll CT, Forsius M, Johannessen M, Kahl JS, Kellogg JH, et al. 1999. Regional trends in aquatic recovery from acidification in North America and Europe. Nature 401:575578

Stoddard JL, Kahl JS, Deviney FA, DeWalle DR, Driscoll CT, Herlihy AT, Kellogg JH, Murdoch PS, Webb JR, Webster KE. 2003. Response of surface water chemistry to the Clean Air Act Amendments of 1990. Response of surface water chemistry to the Clean Air Act Amendments of 1990. Research Triangle Park (NC) and Washington DC: US Environmental Protection Agency. EPA/620/R03/001.

Strayer DL. 2013. Understanding how nutrient cycles and freshwater mussels (Unionida) affect one another. Hydrobiologia 735:277-292.

Strayer DL, Malcom HM. 2012. Causes of recruitment failure in freshwater mussel populations in southeastern New York. Ecol App/ 22:1780-1790.

Strayer DL, Downing JA, Haag WR, King TL, Layzer JB, Newton TJ, Nichols SJ. 2004. Changing perspectives on pearly mussels, North America's most imperiled animals. BioScience 54:429-439.

Stuart SN, Chanson JS, Cox NA, Young BE, Rodrigues ASL, Fishman DL, Waller RW. 2004. Status and trends of amphibian declines and extinctions worldwide. Science 306:1783-1786.

Thomas P, Rahman MS, Khan IA, Kummer JA. 2007. Widespread endocrine disruption and reproductive impairment in an estuarine fish population exposed to seasonal hypoxia. Proc $R$ Soc B 274:2693-2701.

Tierney GL, Fahey TJ, Groffman PM, Hardy JP, Fitzhugh RD, Driscoll CT. 2001. Soil freezing alters fine root dynamics in a northern hardwood forest. Biogeochemistry 56:175-190.

[USEPA] US Environmental Protection Agency. 2009. Risk and exposure assessmen for review of the Secondary National Ambient Air Quality Standards for oxides of nitrogen and oxides of sulfur. Washington DC: USEPA EPA-452/P-09-004a.

[USEPA] US Environmental Protection Agency. 2013a. 2011. National listing of fish advisories. Washington DC: USEPA. EPA-820-F-13-058.

[USEPA] US Environmental Protection Agency. 2013b. Aquatic life ambient water quality criteria for ammonia-freshwater 2013. Washington DC: USEPA. EPA 822-R13-001.
US Environmental Protection Agency/US Geological Survey/USFWS. 2012. Toxic contaminants in the Chesapeake Bay and its watershed: Extent and potential biological effects. Annapolis (MD): USEPA Chesapeake Bay Program. $175 \mathrm{p}$.

[USFWS] US Fish and Wildlife Service. 2009. North Atlantic Landscape Conservation Cooperative Development and Operations Plan. Hadley (MA): USFWS. 38 p.

Wake DB, Vrendenburg VT. 2008. Are we in the midst of the sixth mass extinction? A view from the world of amphibians. Proc Natl Acad Sci USA 105:1146611473.

Waller K, Driscoll CT, Lynch J, Newcomb D, Roy K. 2012. Long-term recovery of lakes in the Adirondack region of New York to decreases in acidic deposition. Atmos Environ 46:56-64.

Wigington PJ Jr, Baker JP, DeWalle DR, Kretser WA, Murdoch PS, Simonin HA, Van Sickle J, McDowell MK, Peck DV, Barchet WR. 1996. Episodic acidification of small streams in the northeastern United States: Episodic Response Project. Ecol App/ 6:374-388.

Williams JD, Warren ML Jr, Cummings KS, Harris JL, Neves RJ. 1993. Conservation status of freshwater mussels of the United States and Canada. Fisheries 18:6-22.

Winder M, Schindler D. 2004. Climate change uncouples trophic interactions in an aquatic ecosystem. Ecology 85:2100-2106.

Wolfe DW, Ziska L, Petzoldt C, Seaman A, Chase L, Hayhoe K. 2008. Projected change in climate thresholds in the Northeastern US: Implications for crops, pests, livestock and farmers. Miti Adap Strat Glob Change 13: 555-575.

Wu RSS, Zhou BS, Randall DJ, Woo NYS, Lam PKS. 2003. Aquatic hypoxia is an endocrine disruptor and impairs fish reproduction. Environ Sci Technol 37:1137-1141.

Yates D, Adams SEM, Angelo SE, Evers DC, Schmerfeld J, Moore MS, Kunz TH, Divoll T, Edmonds ST, Perkins C, et al. 2014. Mercury in bats from the northeastern United States. Ecotoxicology 23:45-55.

Yates D, Mayack D, Munney K, Evers DC, Taylor RJ, Kaur T, Major A. 2005. Mercury levels in mink and river otter in northeastern North America. Ecotoxicology $14: 263-274$.

Yu X, Driscoll CT, Montesdeoca M, Evers DC, Duron M, Williams K, Schoch N, Kamman NC. 2011. Spatial patterns of mercury in biota of Adirondack, New York lakes. Ecotoxicology 20:1543-1554. 